\title{
Permian gastropods from the Tak Fa Limestone, Nakhon Sawan, Northern Thailand
}

\author{
Chatchalerm KetWetsuriya, AleXAnder NütZel \& Pitsanupong KanjanApayont
}

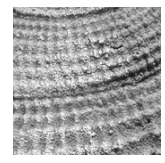

A silicified Middle Permian (Wordian) gastropod fauna is reported from the Tak Fa Limestone from Northern Thailand. It is the first diverse Permian gastropod fauna known from Thailand. The fauna comes from shallow water carbonates that are rich in fusulinids, sponges and calcareous algae. Forty gastropod species are reported, among them 17 nominate species and 23 species in open nomenclature. Thus, this fauna represents one of the richest Permian gastropod faunas known from Southeast Asia. Twelve species and one genus are new to science (all new taxa authored by Nützel \& Ketwetsuriya). The new genus is Takfaia. The new species are Pharkidonotus khaonoiensis, Khumerspira thailandensis, Baylea? umbilicata, Takfaia kuesi, Glabrocingulum magnum, Knightinella ornata, Anomphalus lateumbilicatus, Yunnania pulchra, Microdoma carinata, Trachydomia takhliensis, Goniasma tricarinata and Cambodgia acuminata. The gastropod fauna is dominated by typical Late Palaeozoic cosmopolitan genera with bellerophontoids and pleurotomariines being most abundant. $\bullet$ Key words: Gastropoda, Late Palaeozoic, Permian, Thailand, silicification, diversity.

Ketwetsuriya, C., Nützel, A. \& Kanjanapayont, P. 2016. Permian gastropods from the Tak Fa Limestone, Nakhon Sawan, Northern Thailand. Bulletin of Geosciences 91(3), 481-513 (24 figures). Czech Geological Survey, Prague. ISSN 1214-1119. Manuscript received June 1, 2016; accepted in revised form June 30, 2016; published online September 27, 2016; issued November 25, 2016.

Chatchalerm Ketwetsuriya \& Pitsanupong Kanjanapayont, Department of Geology, Faculty of Science, Chulalongkorn University, 10330 Bangkok,Thailand; ketwetsuriya.c@gmail.com, pitsanupong.k@hotmail.com • Alexander Nützel (corresponding author), SNSB-Bayerische Staatssammlung für Paläontologie und Geologie, Department of Earth and Environmental Sciences, Palaeontology \& Geobiology, Geobio-Center LMU, Richard-Wagner-Str. 10, 80333 München, Germany; a.nuetzel@lrz.uni-muenchen.de

The present contribution reports and describes a Middle Permian (Wordian) gastropod fauna from the Tak Fa Formation of the Saraburi Group, Nakhon Sawan, North Thailand (informally known as Tak Fa Limestone). The Tak Fa Limestone is fossiliferous and yields a diverse Permian invertebrate fauna. The present gastropod fauna has previously been reported in a preliminary note by Ketwetsuriya et al. (2014) based on silicified shells weathering out at the surface of calcareous rocks. Meanwhile, the carbonate samples have been dissolved and numerous silicified gastropod shells have been recovered. With 40 species, the present fauna is one of the most diverse Permian gastropod faunas from Southeast Asia supplementing our knowledge of Middle Permian gastropod distribution in this region considerably.

Previously, there have been few reports or mentions on Permian gastropods from Thailand. Grant (1976) studied Permian brachiopods from South Thailand and mentioned the presence of platyceratids and pleurotomarioids. Waterhouse (1982) studied an early Permian invertebrate fauna from the Kaeng Krachan Group and mentioned presence of the gastropod genus Peruvispira. Sone (2010) reported the species Magnicapitatus huazhangae from the Middle Permian (Guadalupian) of East Thailand and this is the only Permian gastropod species described from Thailand (type locality) to this point.

\section{Geological setting}

The Permian limestones yielding the studied gastropods are exposed along Khao Noi hill, located in Takhli district, Southeast of Nakhon Sawan province, ca $80 \mathrm{~km}$ south of Nakhon Sawan City, Northern Thailand, $15^{\circ} 18^{\prime} 51.801^{\prime \prime} \mathrm{N}, 100^{\circ} 26^{\prime} 30.358^{\prime \prime} \mathrm{E}$ (Fig. 1). The Permian limestone succession in the study area is part of the Tak Fa Formation of the Saraburi Group. The Tak Fa Formation was named by Nakornsri $(1977,1981)$ who published a geological map of the Amphoe Ban Mi area. The 


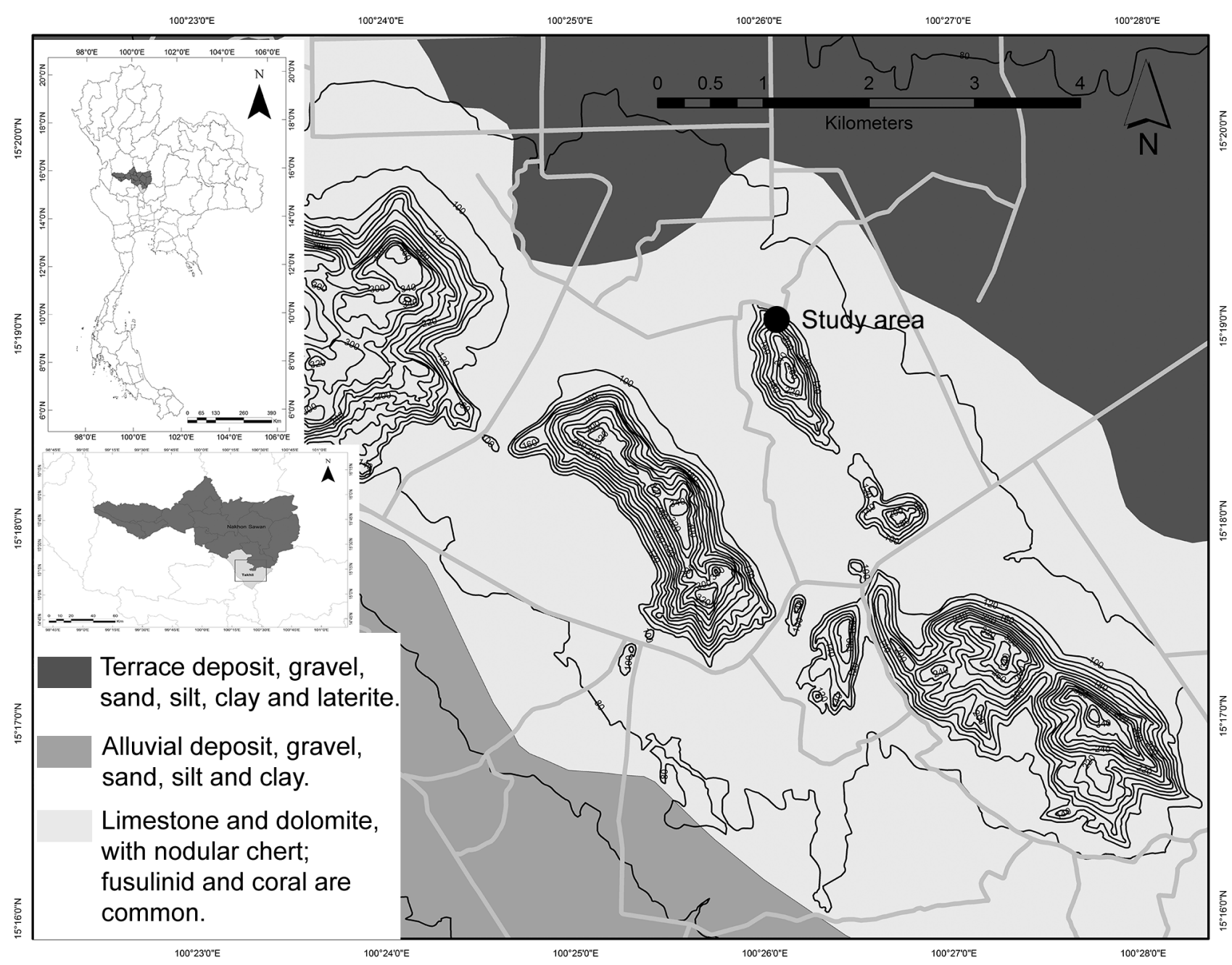

Figure 1. Geological map and locality of the studied section that produced the silicified gastropods at Khao Noi hill, Takhli district, Nakhon Sawan province, North Thailand.

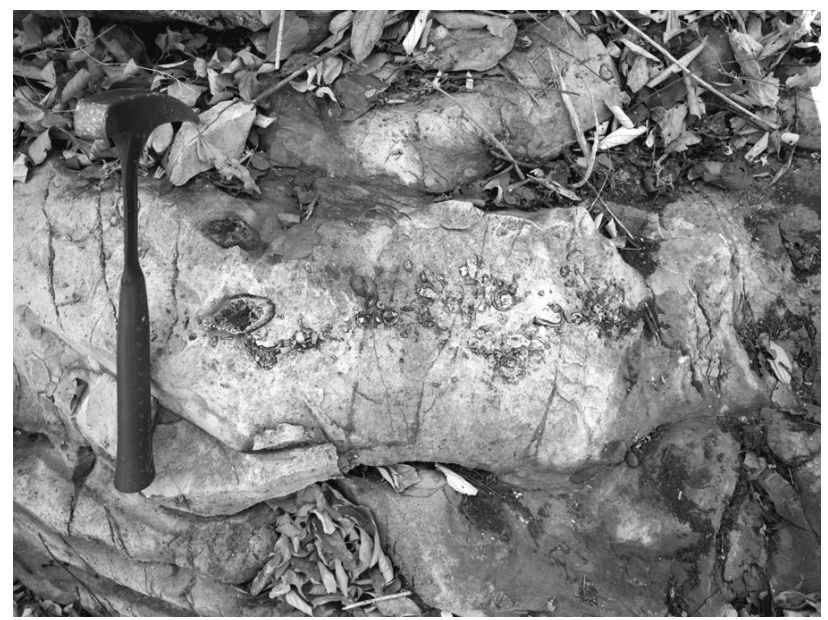

Figure 2. The fossiliferous limestone (middle layer) from which the studied samples were collected.
Tak Fa Formation comprises limestone interbedded with argillaceous limestone, mudstone and dolostone. Parts of the limestone succession yield chert nodules and are fossiliferous. The invertebrate fossils in this formation comprise fusulinids, corals, brachiopods, gastropods, bryozoans and others.

The Tak Fa Formation is the part of Khao Khwang platform (Wielchowsky \& Young 1985, Ueno \& Charoentitirat 2011) located at the western margin of the Indochina Terrane (Metcalfe \& Sone 2008). Fusulinids indicate a Yakhtashian or Artinskian (late Early Permian) to Midian or Capitanian (late Middle Permian) age for the fusulinoidean limestones of the Tak Fa Limestone in the East of the Nakhon Sawan province (Napradit 2005). In the studied section yielding the gastropods, the Tak Fa Limestone has a Wordian age.

The exposed section of fossiliferous limestones of the Tak Fa Formation yielding the studied gastropods has a thickness of approximately 35 meters. It consists of thick to very thick-bedded, light grey (lower part) to dark grey (upper part) limestones. The beds dip with $30^{\circ}$ to the West. The lower part of the section is dominated by thick-bedded 
Figure 3. Limestone block as an example for preservation; silicified shell material weathered out from a grey, micritic limestone; width $\mathrm{ca} 15 \mathrm{~cm}$.

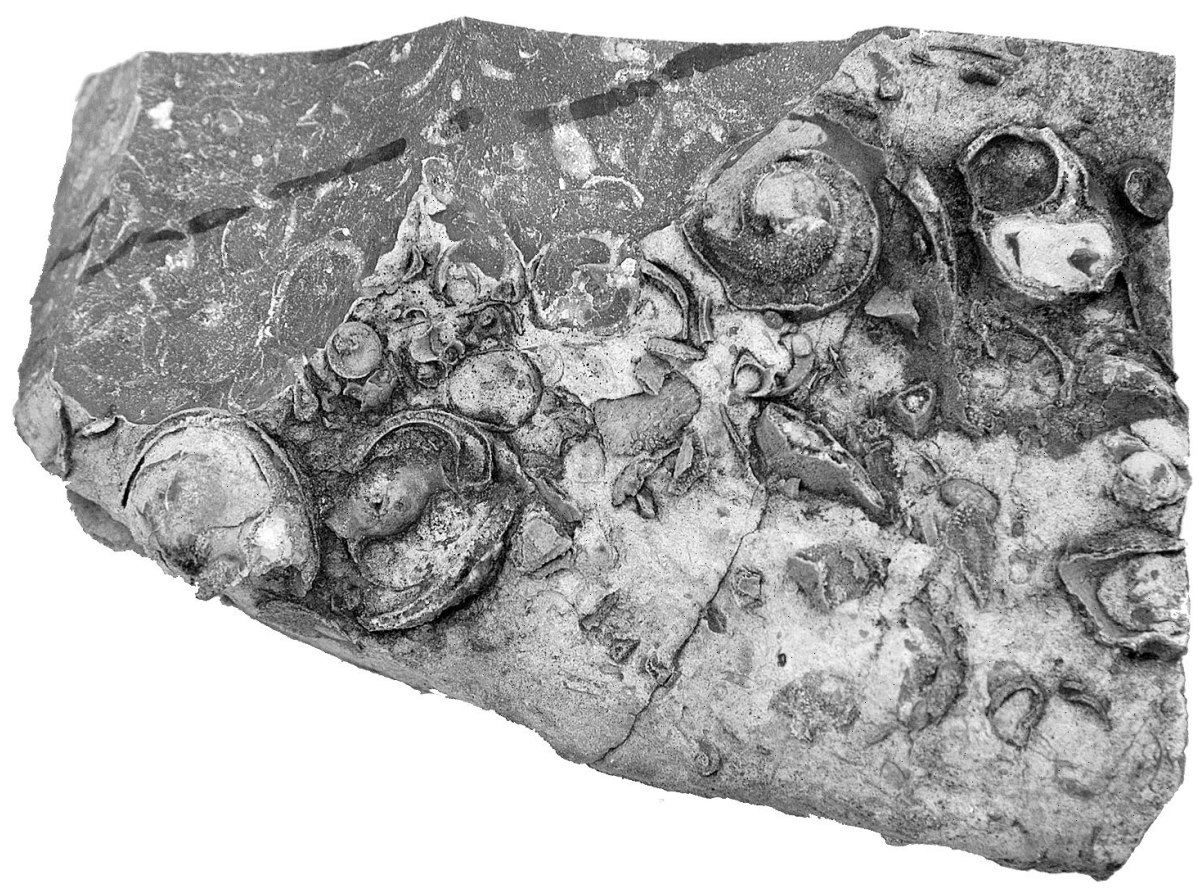

packstones. Fusulinids, rugose corals, bryozoans, crinoid stems and gastropods are commonly found (only few samples were collected from this bed). The middle part of the sections consists of thick-bedded wackestones. The upper part of the section is composed of very thick-bedded, grey to dark-grey packstones with black chert nodules at the base and locally interbedded with laminated dark-grey shale (Fig. 2). Most of the studied samples were collected from the upper beds. In these beds, gastropods and fusulinids are abundant. Silicified gastropods weather out from the rock (Figs 2, 3). In the field, colonial and solitary rugose corals, brachiopods, crinoid stems and sponges could be observed.

\section{Materials and methods}

Samples were preferentially taken where silicified gastropods weathered out from the rock. The samples yielding the silicified fauna were collected by the first author in 2010, 2013 and 2015. They were dissolved in formic acid at the Bayerische Staatssammlung für Paläontologie und Geologie in Munich, Germany. Most samples came from two stratigraphic layers at the north of an isolated hill (Fig. 1). After etching, the material was sieved under rinsing water at a mesh size of $0.5 \mathrm{~mm}$. All fossils including the gastropods were picked from the washed residues. Gastropods were sorted according to species and samples. Representatives of each gastropod species and some other species were whitened with ammonium-chloride and documented with microphotography

\section{Biota in the studied samples}

Most of the samples that were dissolved were very fossiliferous and produced abundant silicified fossils. However, most of the fossil material consists of unidentifiable shell fragments. Remains of calcareous algae such as codiaceaens (Fig. 4A) and the dasycladacean Mitzia sp. (Fig. 4B) were abundant in some of the gastropod-rich samples. Silicified fusulinids are abundant in most of the samples (Fig. 4C) and thin-sections showed that fusulinids are present in rock-forming quantities. The presence of these algae and foraminiferans suggest a tropical shallow water environment. The samples also yielded rather large sclerites probably deriving from sponges (Fig. 4D, E). Among other invertebrates, gastropods are by far the most diverse and abundant group. They are commonly fragmented but more or less complete specimens are also present. The strong dominance of gastropods is remarkable but it must be taken into account that gastropod-rich rocks were sampled preferentially in the field. The samples also yielded few small articulate brachiopods (Fig 4F, left), scaphopods (Fig. 4F, right), polyplacophoran plates (Fig. 4G), small nuculoid bivalves (Fig. 4H, I) and other bivalves (Fig. 4J, K). The few present brachiopods and bivalves have commonly attached valves indicating that the fauna is basically autochthonous and not transported.

A quantitative census of the fossils in the studied samples is difficult because of the high degree of fragmentation and the problematic preservation of many of the fossils. However, it seems clear that the fauna is very diverse with a low dominance. A comprehensive study 
on the diversity of the Tak Fa fauna will be attempted at a later point.

\section{General remarks on the gastropod fauna}

As mentioned, except for fusulinids, gastropods are the most abundant and diverse group in the present collection from the Tak Fa Limestone. According to the present genera, it is a typical Late Palaeozoic gastropod fauna encompassing cosmopolitan genera such as Euphemites, Pharkidonotus, Glabrocingulum, Anomphalus, Yunnania, Microdoma, Trachydomia, Goniasma and others. Other genera seem to be restricted to Southeast Asia according to the current state of knowledge. Although a complete census is difficult because of the poor preservation and fragmentation of many of the gastropods, it is obvious that bellerophontoids, pleurorotomariines and trochoids represent the most abundant groups with Warthia and other bellerophontoids as well as Glabrocingulum magnum sp. nov. being most abundant. This dominance of basal gastropod clades is certainly a Palaeozoic aspect of this fauna. This separates it from the diverse fauna of Perak, Malaysia and the Japanese Akasaka Limestone in which caenogastropods play a much larger role (Batten 1985, Nützel \& Nakazawa 2012). As mentioned, the strong gastropod dominance in the studied samples is a remarkable aspect of this fauna but the picture is biased because rocks with gastropods were preferentially sampled. Further studies are needed to test whether gastropod dominance is a real phenomenon in the Tak Fa Limestone.

\section{Preservation}

The silicification is relatively coarse so that certain morphological features are obscured e.g., the growth line pattern is not visible in most of the specimens. This represents a major handicap for identification, especially in pleurotomariines and muchisoniines in which presence and position of the selenizone or sinus is of great diagnostic relevance. Protoconchs are not or not sufficiently preserved in the present collection. As a consequence open nomenclature was used for many species. On the other hand, preservation was sufficiently good to assign specimens to genera and to characterize several species including new taxa.

\section{Repository}

The studied material is housed in the Bayerische Staatssammlung für Paläontologie und Geologie (Bavarian State Collection for Palaeontology and Geology) in Munich, Germany under the general repository number
SNSB-BSPG 2014 XI. Some of the paratypes are housed in the Chulalongkorn University, Museum of Zoology, Bangkok, Thailand (CUMZ).

\section{Systematic palaeontology by Alexander Nützel \& Chatchalerm Ketwetsuriya}

The classification used herein is based on Wenz (1938-1844), Knight et al. (1960), Bouchet et al. (2005) and Bouchet et al. (in review).

Class Gastropoda Cuvier, 1795

Subclass Amphigastropoda Simroth, 1906

Order Bellerophontida Ulrich \& Scofield, 1897

Superfamily Bellerophontoidea McCoy, 1852

Family Euphemitidae Knight, 1956

\section{Genus Euphemites Warthin, 1930}

Type species. - Bellerophon urii Fleming, 1828, Great Britain, Carboniferous.

\section{Euphemites graffhami Moore, 1941}

Figure 5F-L

1941 Euphemites graffhami sp. nov.; Moore, p. 142, pl. 2, figs $1-5$.

Material. - Two specimens, SNSB-BSPG 2014 XI 58, 105.

Description. - Shell bellerophontiform, anomphalous, with geniculate curvature of body whorl in lateral view; larger specimen $30 \mathrm{~mm}$ long, $28 \mathrm{~mm}$ wide, $25 \mathrm{~mm}$ thick; first geniculation in aperture, second on opposite side; shell ventrally flattened between geniculations and rounded dorsally; body whorl smooth, probably covered with secondary shell deposits, neither growth lines, selenizone or slit observable; dorsal part of body whorl with broad shallow central furrow; inductura inside aperture with about 10 spiral lirae; aperture strongly bent kidney-shaped in transverse section with steep lateral lips, rounded anterior lip with central sinus (where shallow median furrow is situated) and a rounded triangular inner lip formed by the previous whorl; lateral lips joining body whorl with an U-shaped sinus in lateral view.

Remarks. - Despite the differences in age and region, we assign the present material to Euphemites graffhami Moore, 1941 from the late Pennsylvanian of Kansas, USA because there are no obvious morphological differences between our material and Moore's (1941) type material as illustrated by this author. The geniculation was not mentioned in 


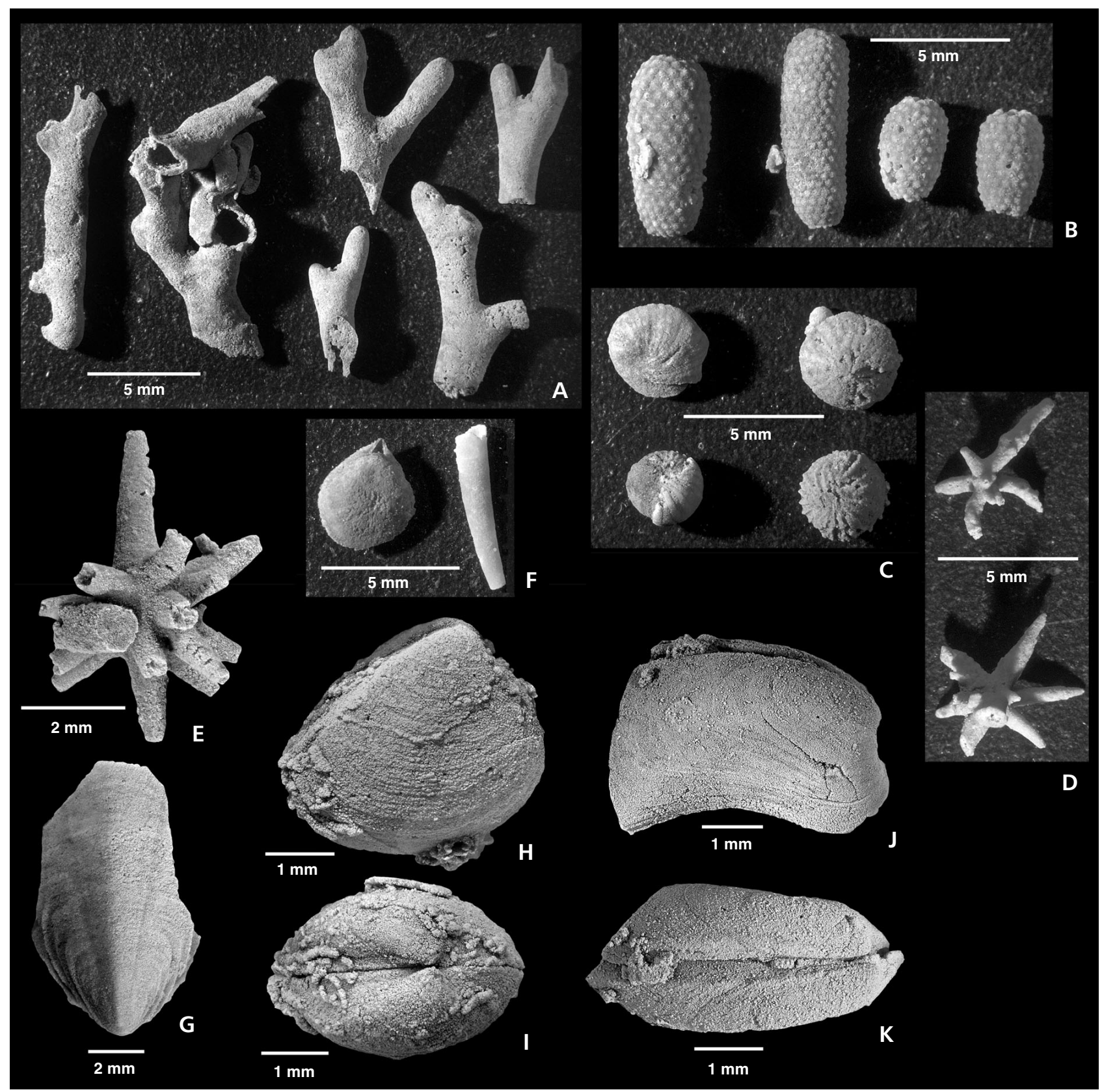

Figure 4. Examples for silicified fossils other than gastropods from the studied samples. $\bullet A$ - codiacean algae. $\bullet$ B - fragments of the dasycladacean algae Mitzia sp. $\bullet \mathrm{C}$ - poorly preserved foraminiferans (fusulinids). $\bullet \mathrm{D}, \mathrm{E}-$ sclerites, probably deriving from sponges. $\bullet \mathrm{F}-$ small articulate brachiopod (left) and scaphopod (right). $\bullet \mathrm{G}$ - plate of polyplacophoran. $\bullet \mathrm{H}$, I - small nuculoid bivalve, SNSB-BSPG 2014 XI 118・・J, K - bivalve, SNSB-BSPG 2014 XI 111.

Moore's description but becomes obvious from his illustrations (Moore 1941, figs 4b, 5b). As pointed out by Yochelson (1960), there are not many distinctly geniculated species of the genus Euphemites. Euphemites imperator Yochelson, 1960 from the Permian of Texas is the most similar species. However, in this species, the spirally ornamented inductura extends much farer outside the aperture. Moreover, the shell Euphemites graffhami is much more flattened ventrally. Euphemites graffhami is similar to E. nodosocarinatus (Hall, 1858) from the Pennsylvanian of the USA as reported by Kues \& Batten (2001). However, this species has many more inductural lirae and according to Yochelson (1960), it has nodes near the selenizone as is also the case in E. callosus (Weller, 1930).

\section{Genus Warthia Waagen, 1880}

Type species. - Warthia brevisinuata Waagen, 1880, Permian, India. 


\section{Warthia cf. brevisinuata Waagen, 1880} Figure 5A-E

cf. 1880 Warthia brevisinuata sp. nov.; Waagen, p. 161, pl. 15 , fig. 6 .

2014 Bellerophon sp. 1; Ketwetsuriya et al., p. 139, pl. 1, figs $a, b$.

Material. - SNSB-BSPG 2014 XI 2, 27 and several other specimens.

Description. - Shell globular bellerophontiform, anomphalous; larger illustrated specimen $4.9 \mathrm{~mm}$ long, $5.3 \mathrm{~mm}$ wide, $4.3 \mathrm{~mm}$ thick (SNSB-BSPG 2014 XI 27); whorl profile and anterior lip evenly rounded; whorls smooth, probably covered with secondary shell layers; whorls kidney-shaped, low in transverse section.

Remarks. - Several relatively small smooth bellerophontoids representing the genus Warthia are present in this collection. Of the numerous described Late Palaeozoic Warthia species, Warthia brevisinuata Waagen, 1880 from the Permian of the Salt Range, Pakistan seems to be most similar. But because of the preservation and the relatively uncharacteristic shell morphology, a safe identification is impossible.

\section{Warthia sp.}

Figure 5M-O

Material. - One specimen, SNSB-BSPG 2014 XI 106.

Remarks. - This shell representing the genus Warthia (31 mm long, $32 \mathrm{~mm}$ wide) resembles the much smaller specimens of Warthia cf. brevisinuata as described above but has callus (inductural) pads on the umbilical region and on the lateral lips. It is possible that these smaller specimens representing Warthia cf. brevisinuata are juveniles and are conspecific with the present mature shell.

Family Bellerophontidae McCoy, 1852

Subfamily Bellerophontinae McCoy, 1852

\section{Genus Bellerophon de Montfort, 1808}

Type species. - Bellerophon vasulites de Montfort, 1808, Devonian, Germany.

\section{Bellerophon sp.}

Figure 6A-E

Material. - Three specimens, SNSB-BSPG 2014 XI 49, 65 (fragment), 107 (fragment).
Description. - Bellerophontid with deeply umbilicated shell; whorls low, broad in transverse section ornamented with distinct collabral lirae separated by wider interspaces; selenizone narrow, bordered by undulating lirae, with distinct lunulae.

Remarks. - Although only fragments are present, the characteristic selenizone and ornament suggest the presence of an additional bellerophontid species in the Tak Fa fauna.

\section{Bellerophon? sp.}

Figure 6F, G

Material. - One specimen, SNSB-BSPG 2014 XI 60.

Remarks. - This anomphalous bellerophontoid shows growth lines and a faint spiral striation. It is $24 \mathrm{~mm}$ long, $28 \mathrm{~mm}$ wide and $26 \mathrm{~mm}$ thick and seems to have a slight depression at the supposed position of the selenizone. The anterior lip is evenly rounded. Preservation is insufficient for a taxonomic assignment. It could represent the genera Bellerophon, Retispira or Warthia with outer shell layers peeled off.

\section{Genus Pharkidonotus Girty, 1912}

Type species. - Bellerophon percarinatus Conrad, 1842; Pennsylvanian, USA.

Pharkidonotus khaonoiensis sp. nov. Figure $7 \mathrm{~A}-\mathrm{K}$

2014 Bellerophon? sp. 2; Ketwetsuriya et al., p. 139, pl. 1, fig. c.

Locus typicus. - Khao Noi hill, Takhli district, Southeast of Nakhon Sawan province, ca $80 \mathrm{~km}$ south of Nakhon Sawan City, Northern Thailand, $15^{\circ} 18^{\prime} 51.801^{\prime \prime} \mathrm{N}$, $100^{\circ} 26^{\prime} 30.358^{\prime \prime} \mathrm{E}$ (Fig. 1).

Stratum typicum. - Tak Fa Formation of the Saraburi Group, Middle Permian, Wordian.

Material. - Holotype: SNSB-BSPG 2014 XI 88; paratypes: SNSB-BSPG 2014 XI 4, 46, 59, 61, CUMZ 7001.

Etymology. - After the Khao Noi hill at which the studied gastropod material was found.

Description. - Shell bellerophontiform, globose, longer than wide, anomphalous; holotype $30 \mathrm{~mm}$ long, $23 \mathrm{~mm}$ 


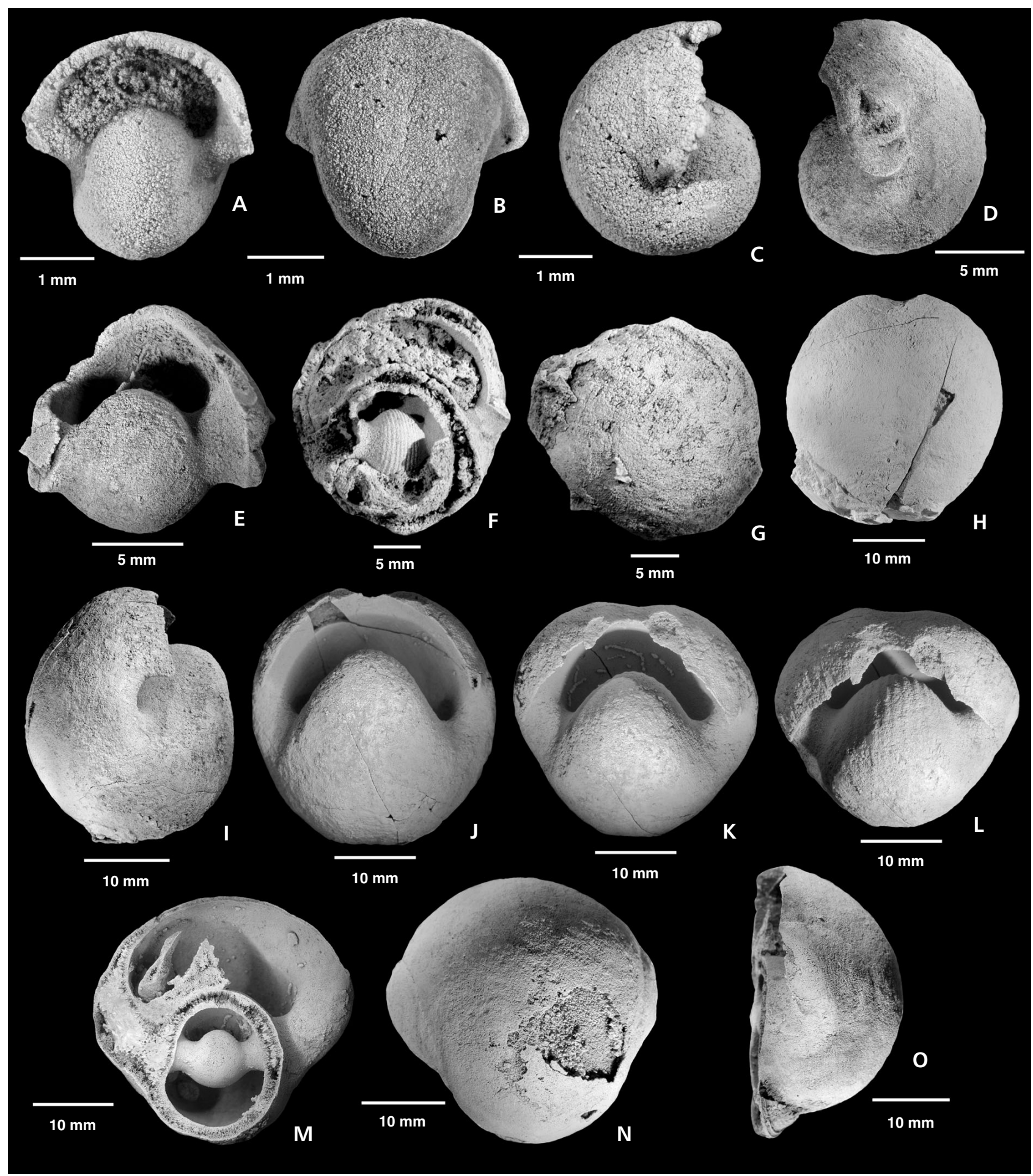

Figure 5. A-C - Warthia cf. brevisinuata Waagen, 1880, SNSB-BSPG 2014 XI 2. • D, E - Warthia cf. brevisinuata Waagen, 1880, SNSB-BSPG 2014 XI 27. $• \mathrm{~F}, \mathrm{G}-$ Euphemites graffhami, SNSB-BSPG 2014 XI 58. $• \mathrm{H}-\mathrm{L}-$ Euphemites graffhami, apertural views at different angles to show spiral lirae within aperture, SNSB-BSPG 2014 XI 105. M-O - Warthia sp., SNSB-BSPG 2014 XI 106.

wide, $26 \mathrm{~mm}$ thick; whorl profile round in lateral view; whorls with pronounced, steeply sided median crest with selenizone; borders of selenizone undulating on last part of the body whorl; outer lip as reflected by growth lines sickle-shaped; aperture kidney-shaped in transverse section with rounded anterior lip, U-shaped at crest; inductura extending from umbilici over some area outside the aperture. 


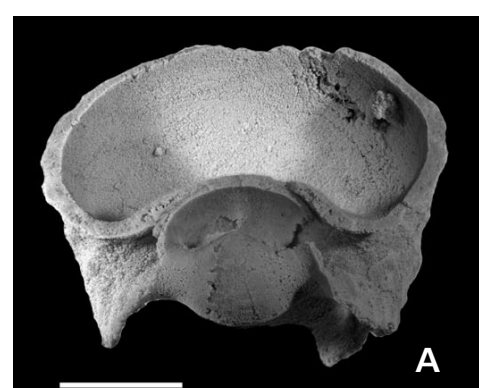

$5 \mathrm{~mm}$

A

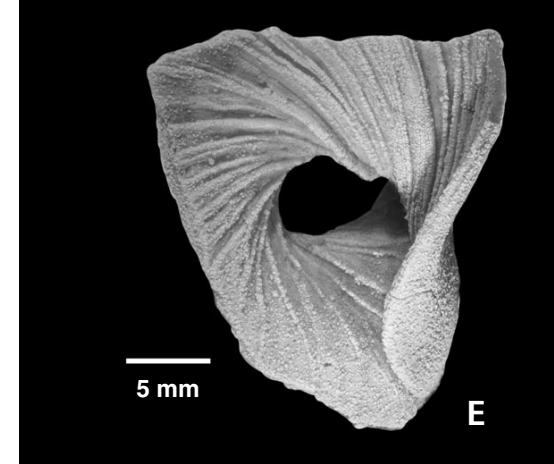

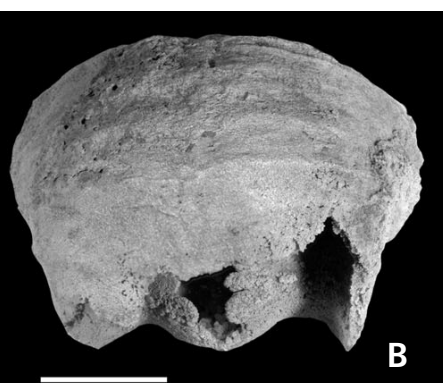

B

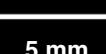

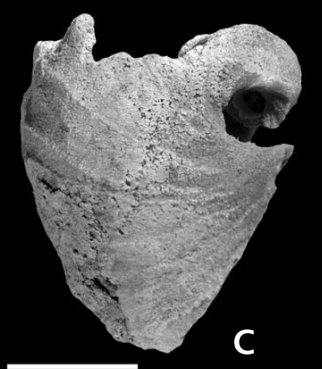

C

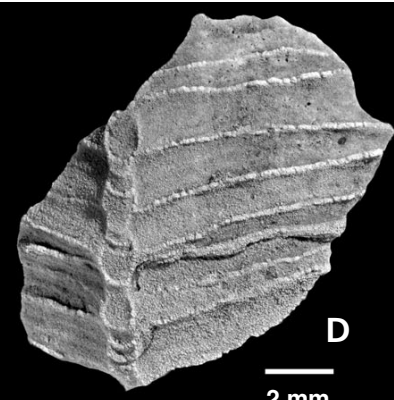

$2 \mathrm{~mm}$

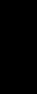

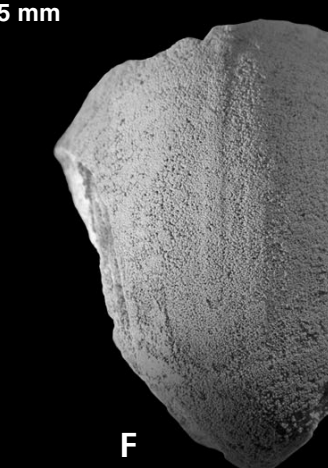

$5 \mathrm{~mm}$

Figure 6. A-C - Bellerophon sp., SNSB-BSPG 2014 XI 49. • D - Bellerophon sp., shell fragment showing collabral lirae and selenizone bordered by undulating lirae, SNSB-BSPG 2014 XI 65. • E - Bellerophon sp., fragment of umbilical region, SNSB-BSPG 2014 XI $107 . \bullet$ F, G - Bellerophon? sp., SNSB-BSPG 2014 XI 60.

Remarks. - Pharkidonotus khaonoiensis sp. nov. resembles Khumerspira thailandensis sp. nov. but is more slender and lacks or has much weaker lateral angulations. Pharkidonotus khaonoiensis has a much more bent aperture in transverse section and the crest is much more pronounced. It also differs in these respects from Bellerophon (Pharkidonotus) altitropis Kulas \& Batten, 1997 (Permian, USA) and moreover, that species is phaneromphalous. Bellerophon deflectus Chronic, 1952 from the Permian of the USA is much broader and its aperture is less bent in transverse section and has a much more pronounced callus. Pharkidonotus khaonoiensis sp. nov. differs from the vast majority of species assigned to Bellerophon in having a strongly elevated crest with steep sides hosting the selenizone. However, some species of Bellerophon including its Devonian type species also have a distinctly elevated crest.

\section{Genus Khumerspira Murata, 1974}

Type species. - Khumerspira ishii Murata, 1974 (in Ishii \& Murata), Middle Permian, Cambodia.

Remarks. - The present species Khumerspira thailandensis sp. nov. is assigned to the genus Khumerspira Murata, 1974 (in Ishii \& Murata) because it has lateral edges, a wide low, subrectangular aperture in transverse section and a sharply projecting median crest. Accordingly, Khumer- spira has also strongly reflexed lateral lips but judging from the illustration of the type species given in Ishii \& Murata (1974), it is not quite clear what this means. Khumerspira thailandensis sp. nov. also resembles species of the genus Pharkidonotus Girty, 1912. However, Pharkidonotus has usually rather strong collabral transverse undulations on the shell and some species also have nodules. Given the shape and gross morphology, Khumerspira thailandensis sp. nov. is closer to the type species of Pharkidonotus as shown by Knight (1941) and Girty (1915) than to that of Bellerophon although this species (type of Pharkidonotus) has much stronger transverse rugae. The subgenus Bellerophon Sorobanobaca Nishida, 1969 (proposed as subgenus of Bellerophon) from the Middle Permian of Japan is also similar but is umbilicated and has a spiral ornament.

Khumerspira and Pharkidonotus are so close to each other morphologically that they may represent synonyms (Mazaev 2016, written communication). Sorobanobaca is also quite similar and might also be synonymous to the other two genera. However, it is beyond the scope of the present contribution to present a formal synonymization. Preliminarily, we suggest treating bellerophontoids with median crest, wide subrectangular aperture and lateral shoulders as follow:

Pharkidonotus: anomphalous, with transverse rugae and also with nodes in several species.

Khumerspira: anomphalous, ornament with growth lines only. 


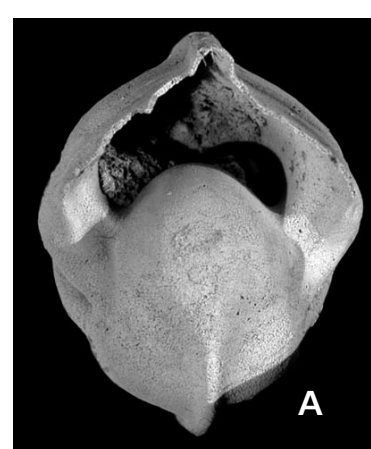

$10 \mathrm{~mm}$

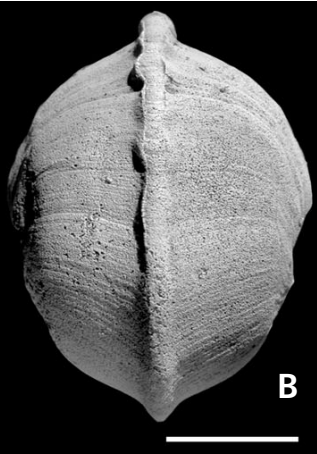

$10 \mathrm{~mm}$ B

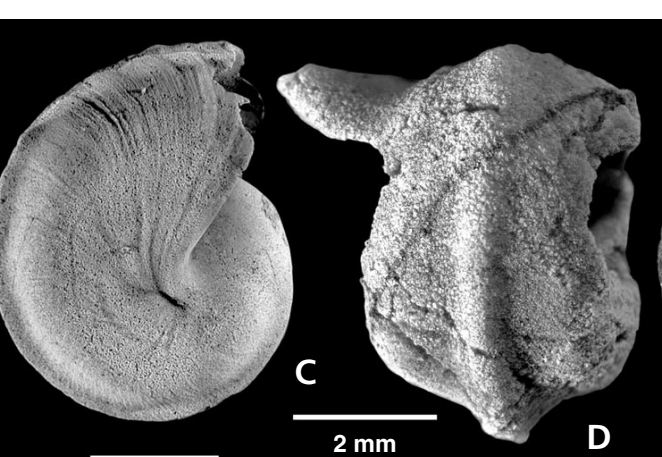

D

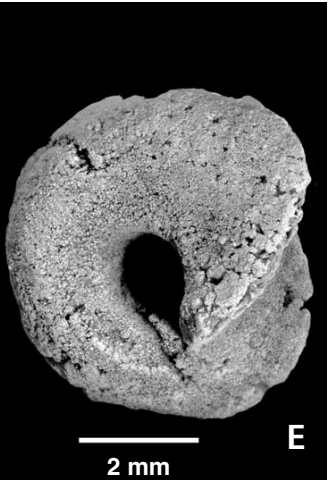

E
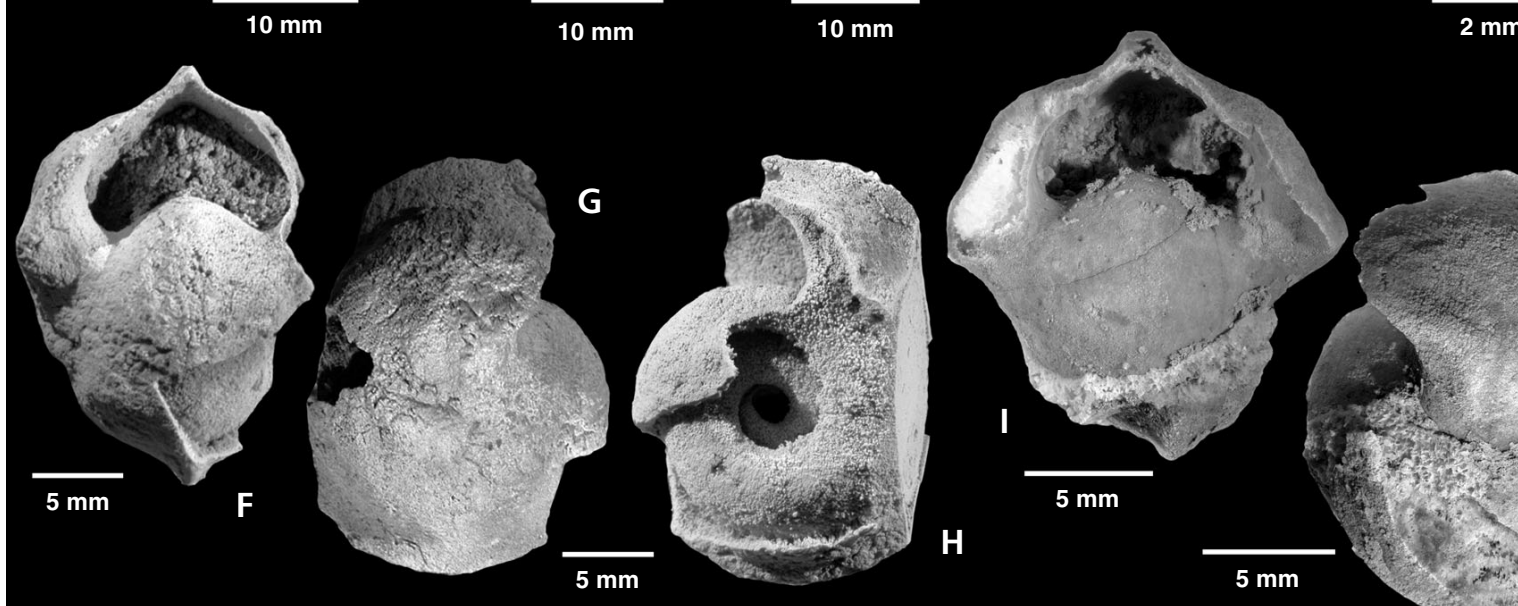
. 


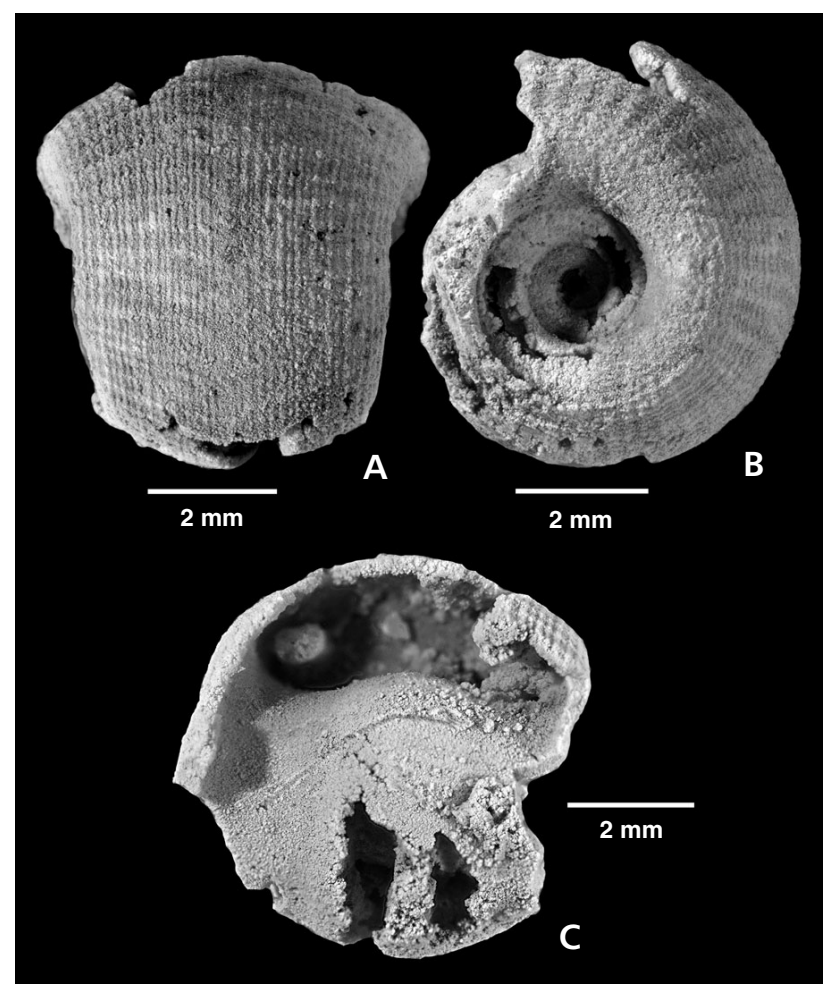

Figure 8. A-C - Retispira lyelli (Gemmellaro, 1890), SNSB-BSPG 2014 XI 32.

weak traces of collabral rugae on dorsal side; growth lines very faint, not well-preserved; aperture broad, anterior lip thin, V-shaped at crest; posterior lip concave due to previous whorl, with parietal inductura and two lateral pads, smooth and thick; umbilici completely covered.

Remarks. - As mentioned above, Khumerspira thailandensis sp. nov. resembles species of the genus Pharkidonotus in gross morphology but lacks strong rugae and nodes. It resembles Bellerophon (Sorobanobaca) matsumotoi Nishida, 1969 from the Middle Permian of Japan. However, this species and subgenus has a collabral and spiral ornament, which is lacking in the present material. Moreover, Nishida (1969) mentioned that his species is phaneromphalous. Khumerspira thailandensis sp. nov. is also similar to Bellerophon khaonoiensis sp. nov. as described above but the shoulder of this species is rounded or only slightly angulated and the anterior lip has steeper sides. Pharkidonotus thailandensis sp. nov. also resembles Bellerophon deflectus Chronic, 1952 (which may be transferred to Khumerspira) from the Early Permian of Arizona but the dorsal crest is less elevated in the latter and it is much larger. Yochelson (1960) reported a similar species from the Permian of Texas as "Bellerophon (?) species" but this shell is widely phaneromphalous. Yochelson (1960) stated that because of the crest, this species would not represent Bellerophon in a strict sense.
Subfamily Knightitinae Knight, 1956

\section{Genus Retispira Knight, 1945}

Type species. - Retispira bellireticulata Knight, 1945, Middle Permian, Texas.

\section{Retispira lyelli (Gemmellaro, 1890)}

Figure 8A-C

1972 Retispira lyelli (Gemmellaro, 1890). - Batten, p. 13, figs 6, 7 (here more synonymy).

Material. - Two specimens, SNSB-BSPG 2014 XI 26, 32.

Remarks. - This rather characteristic species was originally described from the Sosio Limestone of Sicily, Italy. Batten (1972) reported it from the Permian of Perak, Malaysia and considered several taxa described from Asia and North America to represent synonyms. The larger present specimen is $6.3 \mathrm{~mm}$ long, $5.7 \mathrm{~mm}$ wide and $4.4 \mathrm{~mm}$ thick. It is distinctly phaneromphalous, has low whorls and an ornament of strengthened growth lines and densely spaced spiral threads.

Basal taxa that are certainly Gastropoda

Superfamily Euomphaloidea White, 1877

Family Euomphalidae White, 1877

\section{Genus Discotropis Yochelson, 1956}

Type species. - Discotropis publicus Yochelson, 1956, Permian, USA.

Remarks. - Discotropis was previously placed in Omphalotrochidae (Knight et al. 1960) but was placed in Euomphalidae by Linsley \& Kier (1984) without explaining on what grounds. The present material does not contribute to solve the question which of these assignments would be the better choice.

\section{Discotropis? sp.}

Figure $9 \mathrm{~A}-\mathrm{C}$

Material. - One specimen, SNSB-BSPG 2014 XI 91.

Description. - Discoidal, widely phaneromphalous dextral shell with lower umbilicus somewhat deeper than upper umbilicus; diameter $2.9 \mathrm{~mm}$, height $1.2 \mathrm{~mm}$; strong angulation above mid-whorl and a further angulation on the upper side of whorls; whorl profile asymmetrical with slope $c a 45^{\circ}$ above angular periphery and much steeper below it; lower side of whorls distinctly convex; transition from whorl face 


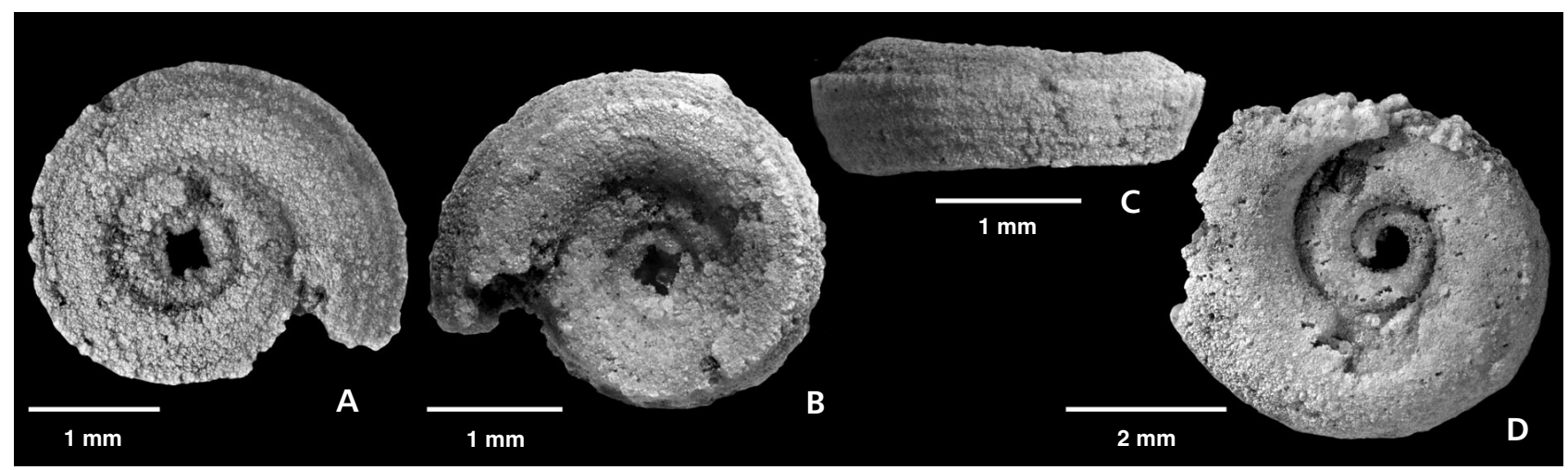

Figure 9. A-C - Discotropis? sp., SNSB-BSPG 2014 XI 91.•D - Euomphalus? sp., SNSB-BSPG 2014 XI 69.

to base distinctly angular; distinct spiral cords present on whorl face, four below periphery and at least one above; suture distinct; aperture subcircular, as wide as high.

Remarks. - The present specimen resembles Discotropis klobukowskii Mansuy, 1912 from the Carboniferous of Yunnan, a species also reported by Delpey (1941) from the Permian of Cambodia. However, that species has a slightly elevated spire, axial sculptural elements and an upper edge. The present species probably represents a new species that may represent the genus Discotropis but the single specimen to is too poorly preserved for a sufficient characterization. The generic and suprageneric assignment of this species is uncertain because tiny planispiral shells are present in various gastropod groups (e.g., Bandel 1988).

\section{Genus Euomphalus Sowerby, 1814}

Type species. - Euomphalus pentangulatus J. Sowerby, 1814, Carboniferous, Great Britain.

\section{Euomphalus? sp.}

Figure 9D

Material. - One specimen, SNSB-BSPG 2014 XI 69.

Description. - Discoidal, widely phaneromphalous shell with both umbilici equally deepened; diameter $23 \mathrm{~mm}$; whorls round, almost circular in transverse section; whorl surface smooth; suture deep.

Remarks. - This small planispiral shell may represent early whorls of an unknown euomphalid.

Unassigned to superfamily

Family Raphistomatidae Koken, 1896

Subfamily Omospirinae Wenz, 1938

\section{Genus Baylea de Koninck, 1883}

Type species. - Trochus yvanii Léveillé, 1835, Carboniferous, Belgium.

Remarks. - Knight et al. (1960) and Batten (1995) placed Baylea in Raphistomatidae Koken, 1896 but Mazaev (2015) placed it in Phymatopleuridae.

Baylea? umbilicata sp. nov.

Figure 10

2014 Worthenia? sp.; Ketwetsuriya et al., p. 140, pl. 1, fig. j.

Locus typicus. - Khao Noi hill, Takhli district, Southeast of Nakhon Sawan province, $c a 80 \mathrm{~km}$ south of Nakhon Sawan City, Northern Thailand, $15^{\circ} 18^{\prime} 51.801^{\prime \prime} \mathrm{N}$, $100^{\circ} 26^{\prime} 30.358^{\prime \prime} \mathrm{E}$ (Fig. 1).

Stratum typicum. - Tak Fa Formation of the Saraburi Group, Middle Permian, Wordian.

Material. - Holotype: SNSB-BSPG 2014 XI 13, paratypes: SNSB-BSPG 2014 XI 22, 23, 29, 31, 97, 102, 103, CUMZ $7002,7003$.

Etymology. - For the distinctly umbilicated base.

Description. - Shell turbinate, moderately high-spired, gradate; holotype comprises about 6 whorls, $8.2 \mathrm{~mm}$ high, $6.4 \mathrm{~mm}$ wide; largest specimen $9.8 \mathrm{~mm}$ high, $6.8 \mathrm{~mm}$ wide; whorls sharply angulated at about mid-whorl and somewhat below middle of spire whorls; whorls with distinctly inclined subsutural ramp above and vertical, concave below angulation; angulation forms crest-like periphery of whorls; transition to base angular; whorls ornamented with numerous densely spaced spiral threads; up to eight spiral 


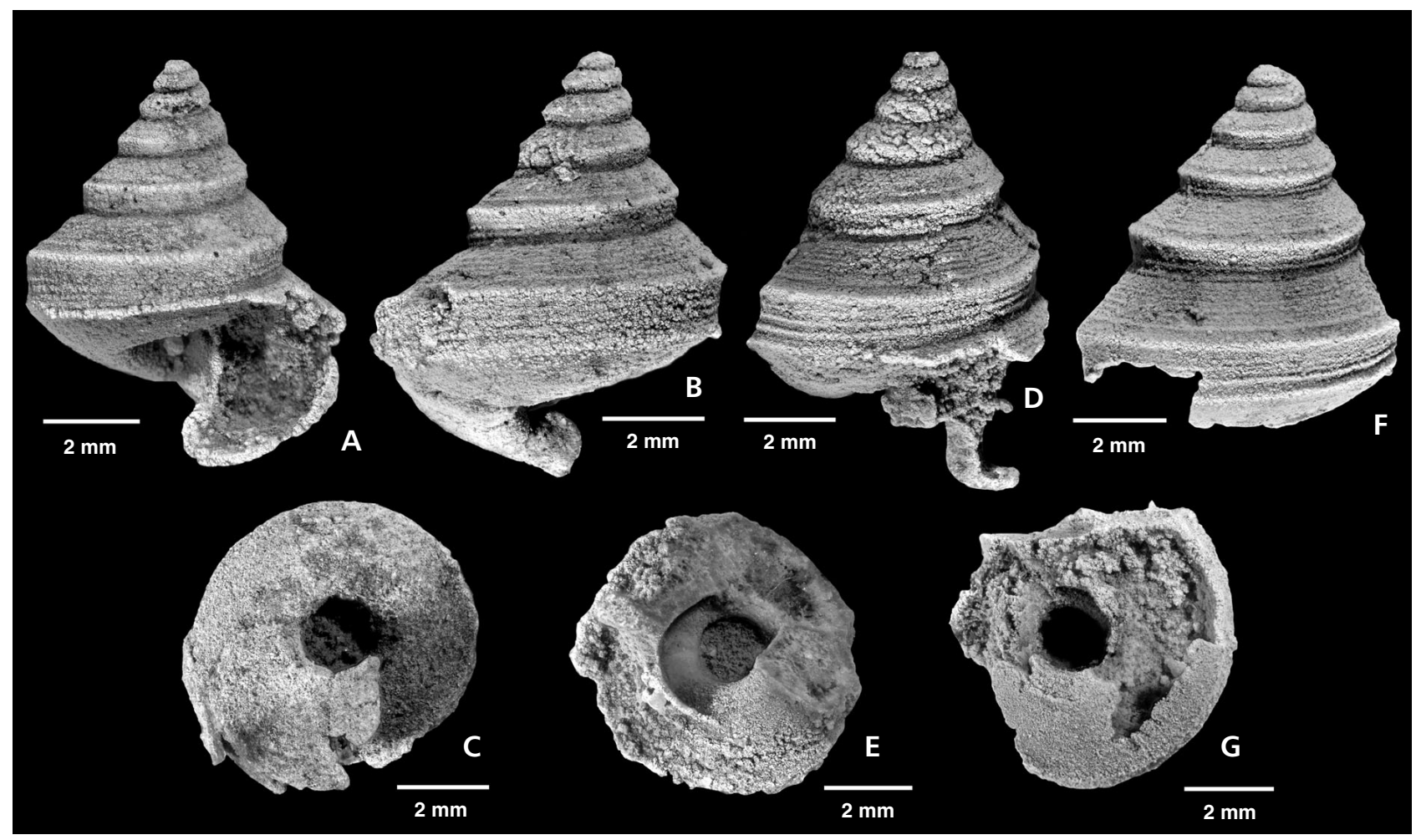

Figure 10. A-C-Baylea? umbilicata sp. nov., holotype, SNSB-BSPG 2014 XI 13. • D, E - Baylea? umbilicata sp. nov., paratype, SNSB-BSPG 2014 XI 22. • F, G - Baylea? umbilicata sp. nov., paratype, SNSB-BSPG 2014 XI 31.

threads present on ramp and at least four below angulation; growth line pattern including selenizone obscured due to preservation; selenizone probably at peripheral angulation of whorls; base flatly convex, without visible ornament, distinctly phaneromphalous with umbilicus surmounted by a rounded edge.

Remarks. - Due to the coarse silicification, growth line pattern including selenizone are obscured in the present material and thus, the generic placement is uncertain. It is likely that the selenizone is situated at the peripheral angulation of the whorls. Baylea? umbilicata sp. nov. is placed tentatively in the genus Baylea based on the gradate spire and the ornament of spiral lirae. The distinctly phaneromphalous base and the angular transition from whorl face to base are unusual for Baylea and differentiate the present species from other species of this genus. It is also possible that Baylea? umbilicata sp. nov. belongs in the genus Platyzona Knight, 1945. The type species of Platyzona is only minutely phaneromphalous and the whorls are usually not strongly angulated but rounded.

A well-preserved specimen of Baylea yvanii, type species of Baylea, from the Mississippian of Belgium was illustrated by Lindström \& Peel (2005, fig. 1a). It is more high-spired than Baylea? umbilicata sp. nov., has a much shallower ramp and thus the spire is more gradate and the transition from whorl face to base is evenly rounded. Its base has only a pseudo-umbilicus. Several Middle Permian species from Russia have been assigned to Baylea. Most are much more high-spired than Baylea? umbilicata sp. nov. and have stronger spiral lirae which are more distant from each other and non of them has such a wide umbilicus. Baylea perthensis Dickins, 1963 from the Permian of Australia is much more low-spired and less distinctly gradate and has a spiral ornament on the base. Baylea? umbilicata sp. nov. resembles species of the genus Biarmeaspira Mazaev, 2006 for instance the Middle Permian species B. angulata (Nechaev, 1894) and B. yakowlewi (Licharev, 1967) but both have strong spiral cords on the base and they are not distinctly phaneromphalous.

Superfamily Trochonematoidea Zittel, 1895

Family Trochonematidae Zittel, 1895

\section{Genus Knightinella Licharev, 1975}

Type species. - Pleurotomaria humerosa Meek \& Hayden, 1858, Carboniferous, USA.

Remarks. - Knightinella was proposed as a subgenus of Amaurotoma Knight, 1945. 


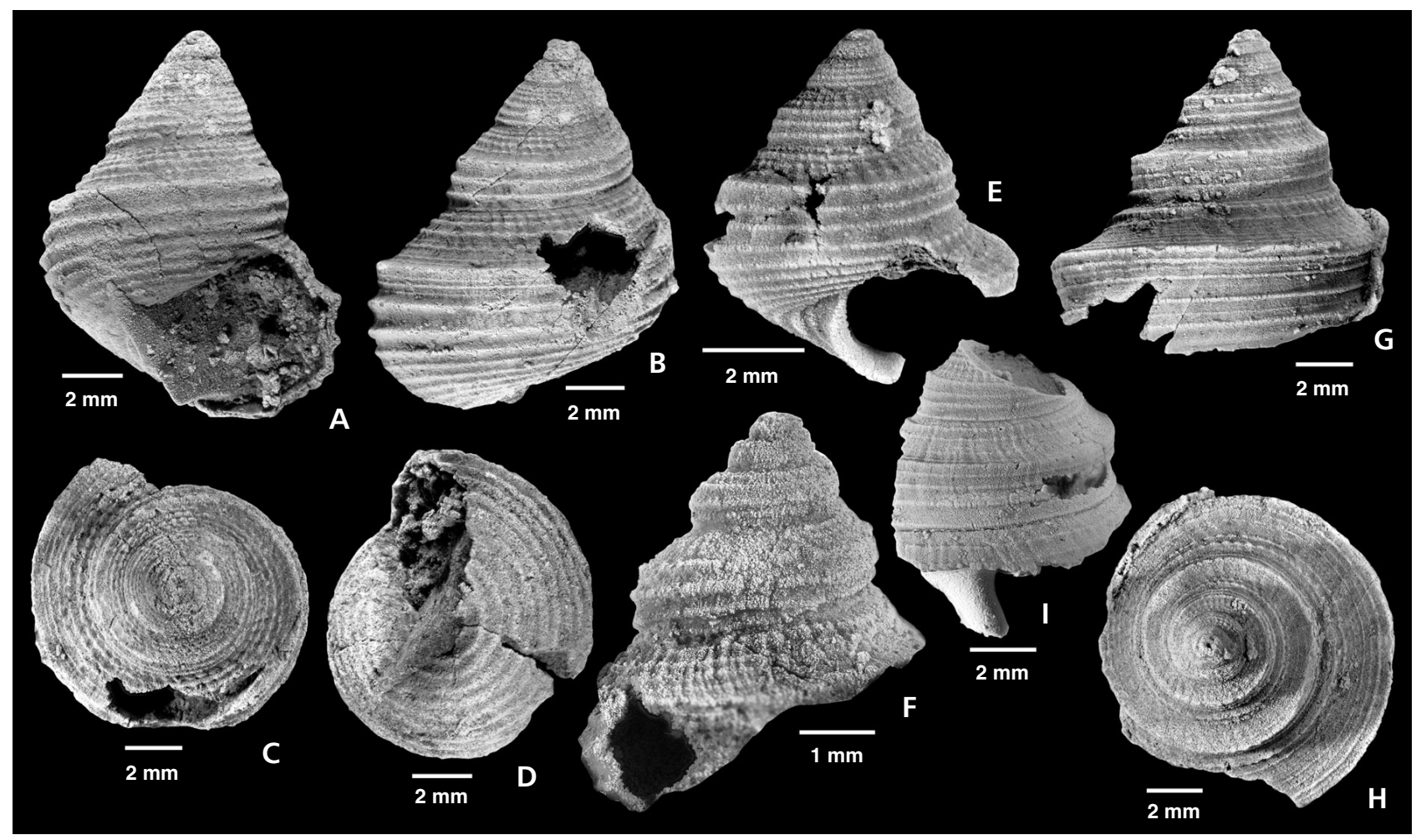

Figure 11. A-D - Knightinella ornata sp. nov., holotype, SNSB-BSPG 2014 XI 39. • E - Knightinella ornata sp. nov., paratype, CUMZ 7004. • F - Knightinella ornata sp. nov., paratype, SNSB-BSPG 2014 XI 9. • G, H - Knightinella sp., SNSB-BSPG 2014 XI $43 . \bullet$ I - Knightinella sp., SNSB-BSPG 2014 XI 110.

\section{Knightinella ornata sp. nov.}

Figure $11 \mathrm{~A}-\mathrm{F}$

2014 Worthenia? sp.; Ketwetsuriya et al., p. 140, pl. 1, fig. i.

Locus typicus. - Khao Noi hill, Takhli district, Southeast of Nakhon Sawan province, ca $80 \mathrm{~km}$ south of Nakhon Sawan City, Northern Thailand, $15^{\circ} 18^{\prime} 51.801^{\prime \prime} \mathrm{N}$, $100^{\circ} 26^{\prime} 30.358^{\prime \prime} \mathrm{E}$ (Fig. 1).

Stratum typicum. - Tak Fa Formation of the Saraburi Group, Middle Permian, Wordian.

Material. - Holotype: SNSB-BSPG 2014 XI 39; paratypes: SNSB-BSPG 2014 XI 9, CUMZ 7004.

Etymology. - Latin ornamented.

Description. - Shell acutely turbiniform, moderately high-spired; holotype (largest specimen) consisting of $\mathrm{ca} 5$ whorls, earliest whorls missing, $13.5 \mathrm{~mm}$ high, $10.2 \mathrm{~mm}$ wide; early teleoconch whorls evenly convex; later, an angulation develops at middle of whorl face; angulation separates adapical slightly convex ramp and a subvertical, slightly convex abapical portion (outer whorl face); base evenly convex with rounded transition to whorl face, anomphalous; early teleoconch whorls with four to six spiral cords, abapical cords stronger; five to six spiral cords and weaker axial ribs or strengthened growth lines present on ramp in mature whorls; strengthened growth lines on ramp curving backward towards angulation; intersections of axial ribs and spiral cords slightly nodular; outer whorl face below angulation ornamented with three strong spiral cords and few weak spiral lirae; base with $c a 10$ distinct spiral cords; aperture circular columellar lip reflexed.

Remarks. - We assign Knightinella ornata sp. nov. to the genus Knightinella Licharev, 1975 based on the gross morphology and the dominant spiral ornamentation. Due to preservation, the growth line pattern is unclear i.e., whether a selenizone is present and if so, how it would look like (these features are not well documented for the type species of Knightinella as well). The juvenile specimen illustrated in Fig. 11F shows backward curving growth lines on the ramp and this suggests that a selenizone is present at the angulation. If the present species had a selenizone at the angulation of the whorls, it could represent the genus Biarmeaspira Mazaev, 2006 (see also Mazaev 2015). Knightinella humerosa (Meek \& Hayden, 1858), the Carboniferous type species of Knightinella has a shallower ramp and the spiral cords are narrower (see Knight 1945, Kues \& Batten 2001). 


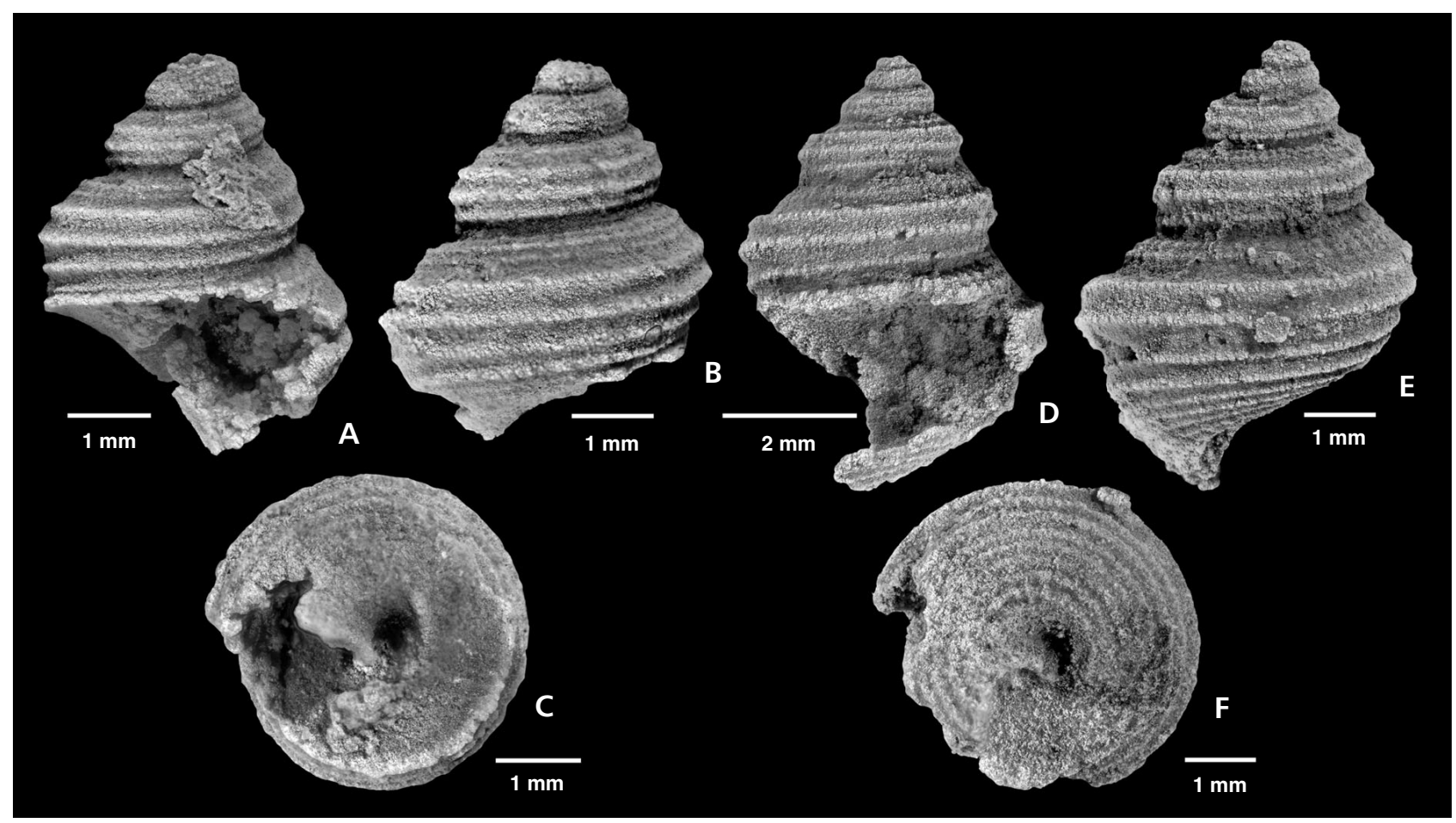

Figure 12. A-C - Amaurotoma? sp., SNSB-BSPG 2014 XI 16. • D-F - Amaurotoma? sp., SNSB-BSPG 2014 XI 64.

Amaurotoma subsinuata (Meek \& Worthen, 1861), type species of the genus Amaurotoma Knight, 1945, lacks ramp and angulation of the whorls according to an illustration given by Knight et al. (1960, fig. 139/4). Apachella Winters, 1956 is more high-spired and the whorls are less angulated. The genus Worthenia yields similar species but is characterized by an elevated, nodular selenizone.

\section{Knightinella sp.}

Figure 11G-I

2014 Worthenia? sp.; Ketwetsuriya et al., p. 140, pl. 1, fig. j.

Material. - Two specimens, SNSB-BSPG 2014 XI 43, 110.

Description. - Turbinate shell with distinctly gradate spire; larger specimen $\mathrm{ca} 6$ whorls, $11.2 \mathrm{~mm}$ high, $11.5 \mathrm{~mm}$ wide; whorls with sharp angulation above mid-whorl; ramp between adapical suture and angulation rather shallow, concave with fine spiral threads which are slightly nodular when intersecting with strengthened growth lines; adapical spiral threads somewhat stronger and more nodular than those lower on ramp; outer whorl face below angulation vertical, slightly concave; outer face with several sharp spiral threads of variable strength but generally stronger than threads on ramp; transition to base angular; base not preserved.

Remarks. - Knightinella sp. resembles Knightinella ornata sp. nov. but has a lower spire, a weaker spiral ornament and the spire is more gradate because the ramp is shallower. As in Knightinella ornata sp. nov., presence and nature of the selenizone are unclear due to preservation. The present shells resemble Knightinella uralica Licharev, 1975 from the Carboniferous of Russia but this species has fewer spiral lirae on whorl face.

\section{Genus Amaurotoma Knight, 1945}

Type species. - Pleurotomaria subsinuata Meek \& Worthen, 1861, Pennsylvanian, USA.

\section{Amaurotoma? sp.}

Figure 12

Material. - Three specimens, SNSB-BSPG 2014 XI 16, 64, 89.

Description. - Shell small, turbinate; largest specimen (SNSB-BSPG 2014 XI 16) comprises ca 3.5 whorls, $5.5 \mathrm{~mm}$ high, $3.6 \mathrm{~mm}$ wide (apex missing); whorls convex, ornamented with three strong spiral cords in abapical 


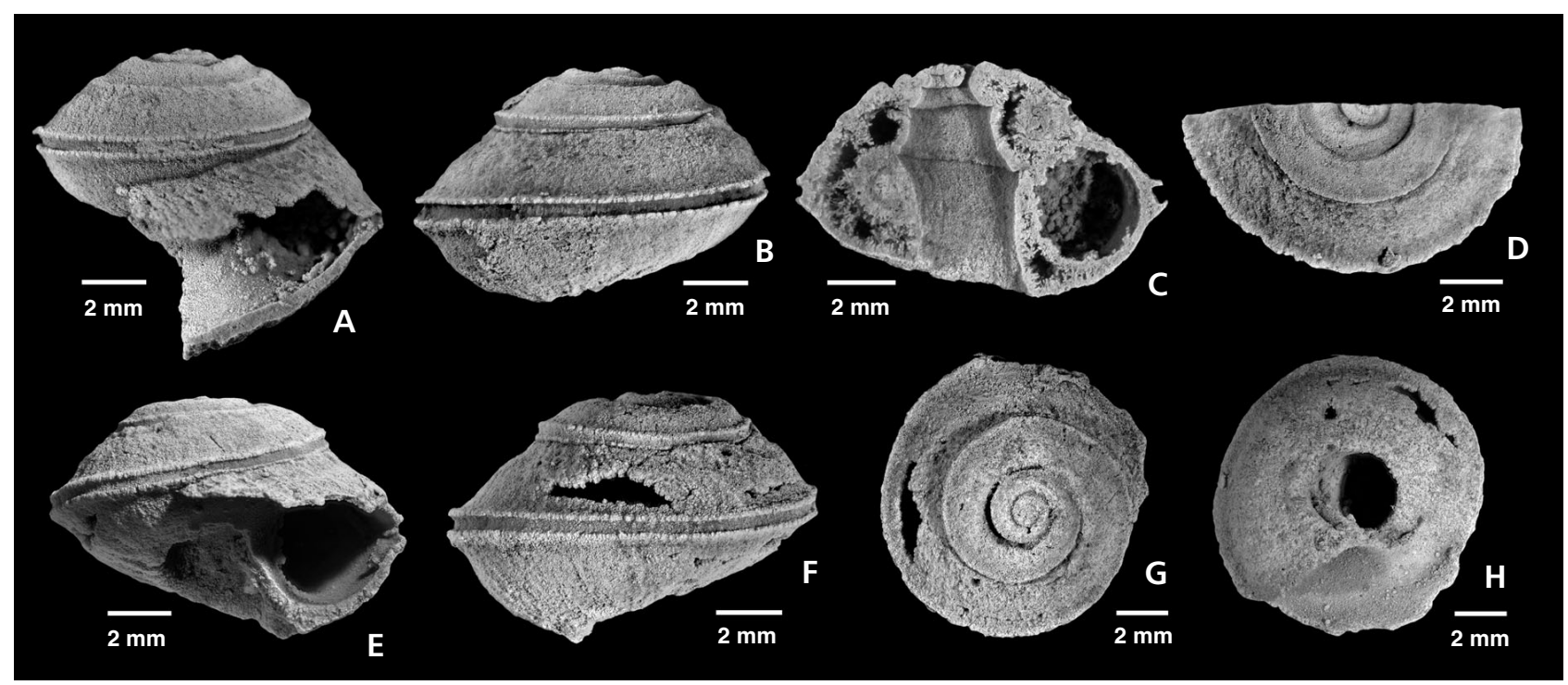

Figure 13. A-D-Takfaia kuesi sp. nov., paratype, SNSB-BSPG 2014 XI 10 (specimen broken in two halves). • E-H - Takfaia kuesi sp. nov., holotype, SNSB-BSPG 2014 XI 42.

portion of whorls; second cord forms periphery at about mid-whorl; adapical portion of whorls forms steep, straight or slightly convex ramp with three weaker spiral cords second of which somewhat more pronounced and angulating whorl face; adapical spiral cords slightly nodular; base convex, minutely phaneromphalous with up to seven distinct, narrowly spaced spiral cords; growth line pattern and aperture unknown.

Remarks. - Amaurotoma? sp. is distinct in this collection. Unfortunately neither growth line pattern nor aperture is known so that a further assignment is impossible. It is also possible that the species belongs to Pleurotomariida. We assign it preliminarily to Amaurotoma because it resembles species such as Amaurotoma subangulatum (Hall, 1858) from the Mississippian of the USA (see Cumings 1906, pl. 25, fig. 32). An assignment to Baylea or Apachella Chronic, 1952 is also possible. Rhabdotocochlis Knight, 1933 from the Late Carboniferous of the USA has a lower spire and less convex whorls.

Subclass Vetigastropoda Salvini-Plawen, 1980

Order Pleurotomariida Cox \& Knight, 1960

(in Knight et al.)

Superfamily Eotomarioidea Wenz, 1938

Family Eotomariidae Wenz, 1938

\section{Genus Takfaia gen. nov.}

Type species. - Takfaia kuesi sp. nov.

Etymology. - After the Tak Fa Limestone.
Diagnosis. - Shell low-spired, trochiform with flattened spire; mature shell broadly trochiform with almost straight to slightly convex whorl face; last portion of body whorl distinctly deflected abapically; selenizone immediately above suture, forming periphery, bordered by distinctly elevated, sharp crests; selenizone concave, vertical, parallel to shell axis; adapical border of selenizone forming angulation with sloping whorl face; whorls smooth, base convex, distinctly phaneromphalous with umbilicus vertical sided, surmounted by a distinct edge.

Remarks. - Takfaia resembles the genus Ambozone Batten, 1972 (type species Ambozone rasmusseni Batten, 1972 from the Middle Permian of Malaysia). However, Ambozone is more low-spired (almost planispiral). Euconospira Ulrich \& Scofield, 1897 is more high-spired and is either anomphalous or only minutely phaneromphalous. The Devonian genus Oehlertia, Perner, 1907 is similar but the selenizone is well above the suture, it is more high-spired and the shell is ornamented with fine but distinct axial lirae. The eotomariid Bradyospira Batten, 1964 from the Permian of Arizona is similar but has a conical, non-depressed spire and the umbilicus is much narrower.

\section{Takfaia kuesi sp. nov.}

Figure 13

2014 Discotropis? sp.; Ketwetsuriya et al., p. 142, pl. 2, fig. e.

Locus typicus. - Khao Noi hill, Takhli district, Southeast of Nakhon Sawan province, ca $80 \mathrm{~km}$ south of Nakhon Sawan City, Northern Thailand, $15^{\circ} 18^{\prime} 51.801^{\prime \prime} \mathrm{N}$, $100^{\circ} 26^{\prime} 30.358^{\prime \prime} \mathrm{E}$ (Fig.1). 
Stratum typicum. - Tak Fa Formation of the Saraburi Group, Middle Permian, Wordian.

Material. - Holotype: SNSB-BSPG 2014 XI 42; paratypes SNSB-BSPG 2014 XI 10, 17, CUMZ 7005, 7006.

Etymology. - After Barry Kues for his work on Late Palaeozoic gastropods.

Description. - Shell low-spired, trochiform with flattened apical whorls; holotype comprises $c a 5$ whorls, $7.7 \mathrm{~mm}$ high, $11.4 \mathrm{~mm}$ wide; largest specimen $9.8 \mathrm{~mm}$ high, $11.4 \mathrm{~mm}$ wide (SNSB-BSPG 2014 XI 10); earliest whorls convex, evenly rounded, very low-spired with spire only slightly elevated; after $c a$ three whorls the shell becomes broadly trochiform with almost straight to slightly convex whorl face; last portion of body whorl distinctly deflected abapically; selenizone immediately above suture, forming periphery, bordered by distinctly elevated, sharp crests; selenizone vertical, parallel to shell axis; adapical border of selenizone forming angulation with sloping whorl face; abapical crest bordering selenizone emerges at suture; suture distinct; selenizone fully exposed when last portion of body whorl becomes deflected downward; whorls smooth, circular in transverse section; base convex, distinctly phaneromphalous with umbilicus opened throughout including initial whorls; umbilicus of last two whorls with vertical, slightly convex whorl sides; umbilicus surmounted by a distinct edge.

\section{Genus Glabrocingulum Thomas, 1940}

Type species. - Glabrocingulum (Glabrocingulum) beggi Thomas, 1940, Carboniferous, England.

\section{Glabrocingulum magnum sp. nov.}

Figure 14

2014 Treposira sp.; Ketwetsuriya et al., p. 139, pl. 1, figs $\mathrm{d}-\mathrm{g}$.

2014 Glabrocingulum sp.; Ketwetsuriya et al., p. 140, pl. 1, fig. h.

Locus typicus. - Khao Noi hill, Takhli district, Southeast of Nakhon Sawan province, ca $80 \mathrm{~km}$ south of Nakhon Sawan City, Northern Thailand, $15^{\circ} 18^{\prime} 51.801^{\prime \prime} \mathrm{N}$, $100^{\circ} 26^{\prime} 30.358^{\prime \prime} \mathrm{E}$ (Fig. 1).

Stratum typicum. - Tak Fa Formation of the Saraburi Group, Middle Permian, Wordian.

Material. - Holotype: SNSB-BSPG 2014 XI 92; paratypes: SNSB-BSPG 2014 XI 3, 12, 24, 25, 33, 44, 48, 50, CUMZ 7007, 7008.
Etymology. - Latin magnum for large.

Description. - Shell trochiform, low-spired, with slightly coeloconoid spire; body whorl height about $65 \%$ of total height; holotype (largest specimen) ca $40 \mathrm{~mm}$ high and wide; apical angle of up to $90^{\circ}$; whorls angulated at about mid-whorl; second angulation at transition to base; outer face between angulations vertical (parallel to shell axis), concave; whorls above adapical angulation straight to slightly concave, forming evenly sloping ramp; narrow concave selenizone on adapical angulation bordered by distinct, sharp spiral lirae; whorls embrace just below selenizone so that selenizone is in suprasutural position in spire whorls; whorls ornamented with a row of subsutural axially elongated nodes which become stronger during ontogeny; in mature specimens this nodular row forms a bulge that is adpressed to previous whorl; remainder ramp with several spiral lirae; abapical portion between carinations with several spiral cords which may be slightly nodular; growth lines prosocline on ramp and prosocyrt below adapical carination; base convex to conical, anomphalous with circumumbilical carination; base with variable number of spiral cords including one formed by carination; basal spiral cords may be nodular, especially in mature whorls; aperture oblique oval.

Remarks. - With up to $40 \mathrm{~mm}$ in height and width, Glabrocingulum magnum sp. nov. is a rather large representative of the genus Glabrocingulum. The strong subsutural nodes and the angulations on the base and at the transition to the base are especially characteristic for this species. There are numerous Late Palaeozoic species of Glabrocingulum most of which are smaller and have a finer ornament. Glabrocingulum coronatum Chronic, 1952 from the Permian Kaibab Formation of Arizona, USA is much smaller, has a lower spire, a much finer ornament and it lacks a carinated and ornamented base (see also Batten 1989, pl. 1, figs 1-23). Glabrocingulum beedei (Mark, 1912) from the Pennsylvanian of Ohio and the Pennsylvanian/Permian transition of New Mexico has a lower spire, is much smaller, subsutural nodes are not as pronounced and it has no pronounced carination at the transition to the base (see Sturgeon 1964, Kues 2004). The Permian species Glabrocingulum sarrauti (Mansuy, 1912) and Glabrocingulum stankovski Mazaev, 2006 are similar but have a lower spire, differ in details of the ornament and have no pronounced basal angulation (see Batten 1972, figs 12, 13; Mazaev 2006, fig. 1).

Order Trochida Cox \& Knight, 1960 (in Knight et al.)

Superfamily Trochoidea Rafinesque, 1815

Family Anomphalidae Wenz, 1938 


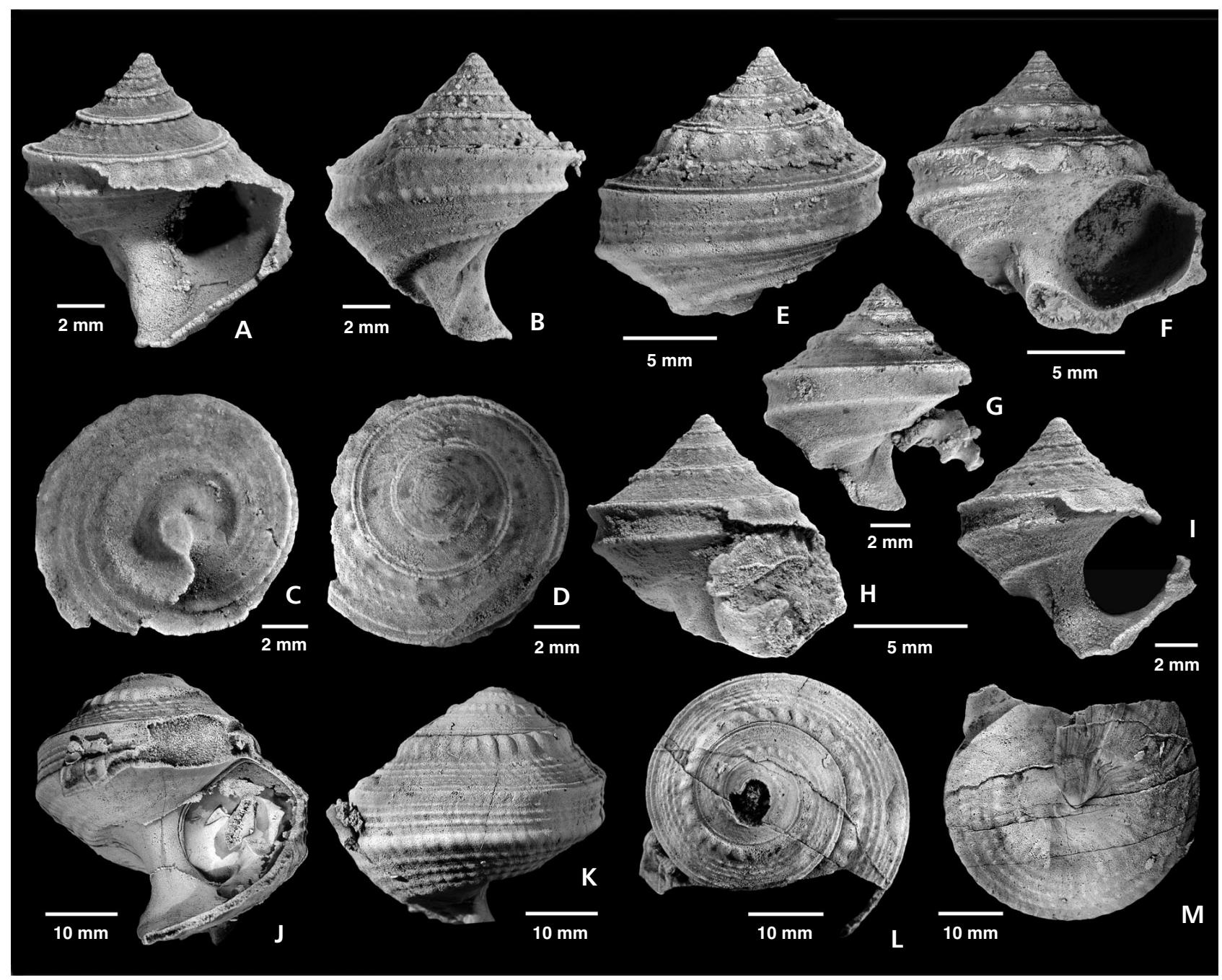

Figure 14. A-D - Glabrocingulum magnum sp. nov., paratype, SNSB-BSPG 2014 XI 12. • E, F - Glabrocingulum thailandensis sp. nov., paratype, SNSB-BSPG 2014 XI 48. • G - Glabrocingulum thailandensis sp. nov., paratype, SNSB-BSPG 2014 XI 50 • H - Glabrocingulum thailandensis sp. nov., paratype, SNSB-BSPG 2014 XI 24. • I - Glabrocingulum thailandensis sp. nov., paratype, SNSB-BSPG 2014 XI 25. • J-M - Glabrocingulum thailandensis sp. nov., holotype, SNSB-BSPG 2014 XI 92.

\section{Genus Anomphalus Meek \& Worthen, 1866}

Type species. - Anomphalus rotulus Meek \& Worthen, 1867, Carboniferous, USA.

\section{Anomphalus lateumbilicatus sp. nov.}

Figure $15 \mathrm{~A}-\mathrm{G}$

Locus typicus. - Khao Noi hill, Takhli district, Southeast of Nakhon Sawan province, $c a 80 \mathrm{~km}$ south of Nakhon Sawan City, Northern Thailand, $15^{\circ} 18^{\prime} 51.801^{\prime \prime} \mathrm{N}$, $100^{\circ} 26^{\prime} 30.358^{\prime \prime} \mathrm{E}$ (Fig. 1).

Stratum typicum. - Tak Fa Formation of the Saraburi Group, Middle Permian, Wordian.
Material. - Two specimens, holotype: SNSB-BSPG 2014 XI 115; paratype: SNSB-BSPG 2014 XI 116.

Etymology. - Latin widely umbilicated.

Description. - Shell minute, discoidal with almost flat, only slightly elevated spire; holotype comprising $c a$ five whorls, diameter $2.7 \mathrm{~mm}, 1.5 \mathrm{~mm}$ high, whorls smooth, with distinctly convex periphery and flatly convex adapical side; whorls increasing slowly in diameter; suture distinct; base with wide umbilicus with circumumbilical rounded edge.

Remarks. - Anomphalus lateumbilicatus sp. nov. differs from all its congeners by its minute size, its very wide 


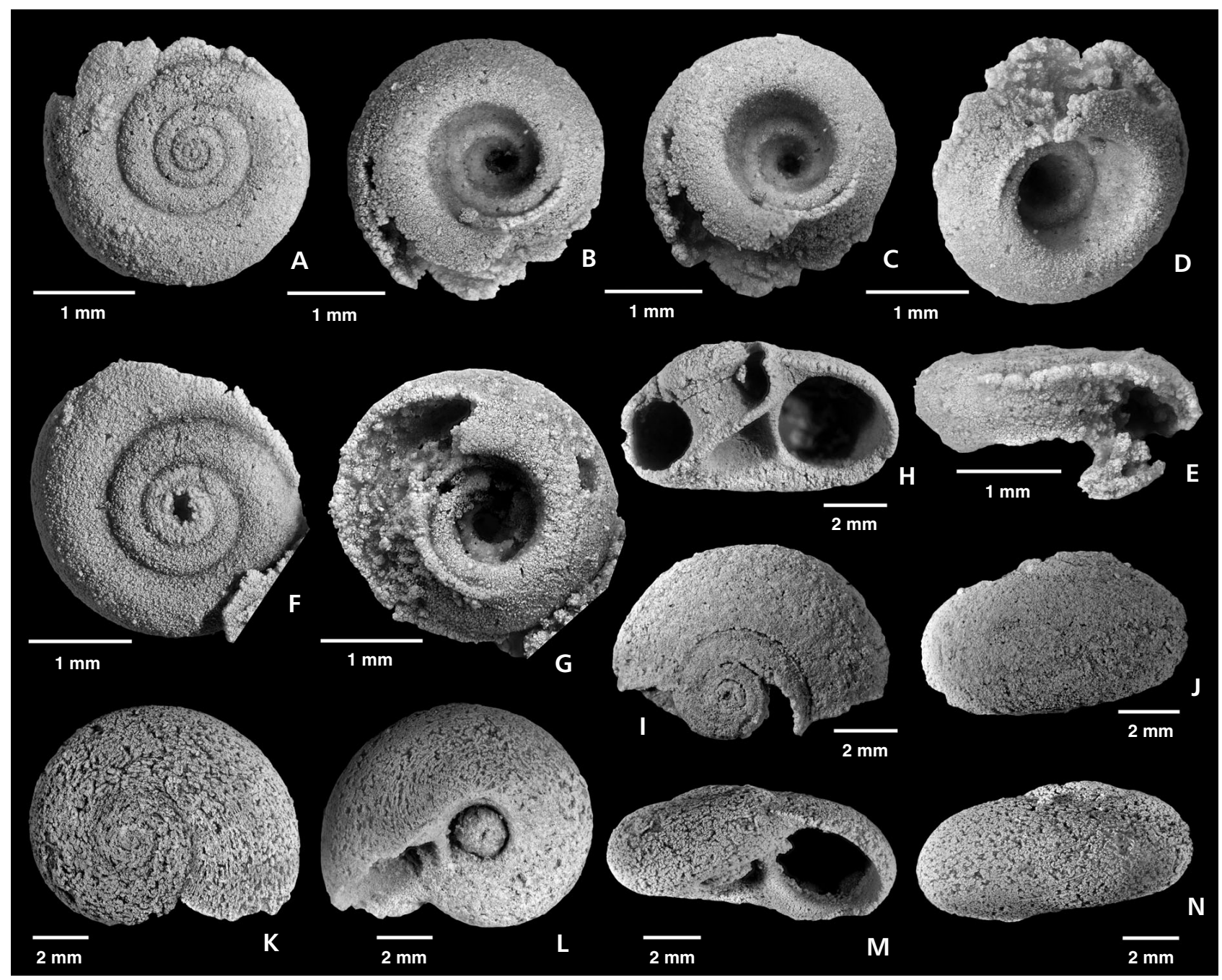

Figure 15. A-E - Anomphalus lateumbilicatus sp. nov., holotype, SNSB-BSPG 2014 XI 115. • F, G-Anomphalus lateumbilicatus sp. nov., paratype, SNSB-BSPG 2014 XI 116. • H-J - Anomphalus sp., SNSB-BSPG 2014 XI 20.・K-N - Anomphalus sp., SNSB-BSPG 2014 XI 28.

umbilicus and the slow increase in whorl diameter. The most similar species is Anomphalus straparoliformis Mazaev, 1997 from the Middle Carboniferous of the Russian Platform. However, this species is much larger (at a comparable number of whorls), the whorls do increase faster in diameter and the umbilicus is smaller in relation to the total width of the shell.

\section{Anomphalus sp.}

Figure $15 \mathrm{H}-\mathrm{N}$

2014 Anomphalus cf. japonicus Nützel, 2012. - Ketwetsuriya et al., p. 140, pl. 2, figs a, b.

Material. - Three specimens, SNSB-BSPG 2014 XI 6, 20, 28.

Description. - Shell small, low-spired, rotelliform; largest specimen with diameter of $5.2 \mathrm{~mm}$, height $4.3 \mathrm{~mm}$; whorls smooth, with convex periphery and flattened ab- and adapical sides, round, circular in transverse section; base distinctly umbilicated with circumumbilical edge; suture shallow, indistinct.

Remarks. - The present specimens are typical representatives of Anomphalus but the preservation is too poor to establish species identity. They resemble Anomphalus japonicus Nützel, 2012 (in Nützel \& Nakazawa) from the Middle Permian of Japan. However, A. japonicus has a much deeper suture and the adapical portion of the whorl is much more convex. Moreover, this species is much smaller. The Late Carboniferous Anomphalus rotulus Meek \& Worthen, 1867 as illustrated by Knight (1933) is similar but has an umbilical plug. Anomphalus umbilicatus Knight, 1933 from the Pennsylvanian of the USA is also very similar. Anomphalus sp. from the Permian of Perak, Malaysia is more high-spired and its umbilicus is 


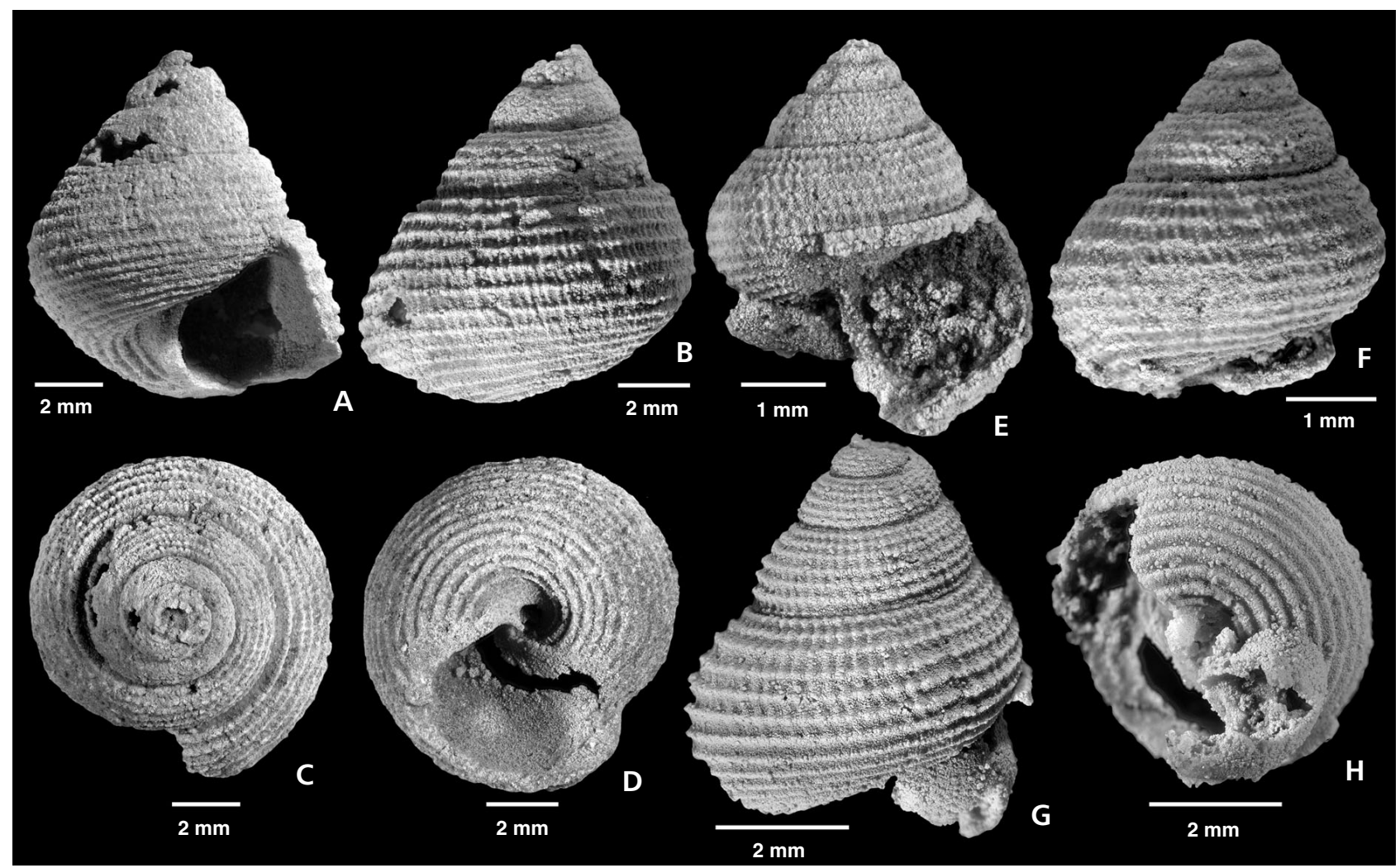

Figure 16. A-D - Yunnania pulchra sp. nov., holotype, SNSB-BSPG 2014 XI 34. • E, F - Yunnania pulchra sp. nov., paratype, SNSB-BSPG 2014 XI 21. • G, H - Yunnania pulchra sp. nov., paratype, SNSB-BSPG 2014 XI 108.

filled with a plug (Batten 1979, figs 10, 11). Anomphalus? sundaicus Wanner, 1942 (according to Yochelson 1956 not a representative of Anomphalus) from the Permian of Timor has a flatter spire and more rapidly increasing whorls. The Anomphalus species that were illustrated by Yochelson (1956) from the Permian of the USA have a flatter spire.

Family Araeonematidae Nützel, 2012

(in Nützel \& Nakazawa)

\section{Genus Yunnania Mansuy, 1912}

Type species. - Yunnania termieri Mansuy, 1912, Late Carboniferous, China.

\section{Yunnania pulchra sp. nov.}

Figure 16

2014 Tapinotomaria? sp.; Ketwetsuriya et al., p. 140, pl. 1, fig. k.

Locus typicus. - Khao Noi hill, Takhli district, Southeast of Nakhon Sawan province, ca $80 \mathrm{~km}$ south of Nakhon
Sawan City, Northern Thailand, $15^{\circ} 18^{\prime} 51.801^{\prime \prime} \mathrm{N}$, $100^{\circ} 26^{\prime} 30.358^{\prime \prime} \mathrm{E}$ (Fig. 1).

Stratum typicum. - Tak Fa Formation of the Saraburi Group, Middle Permian, Wordian.

Material. - Holotype: SNSB-BSPG 2014 XI 34; paratypes: SNSB-BSPG 2014 XI 21, 108, CUMZ 7009, 7010.

Etymology. - Latin beautiful.

Description. - Shell turbiniform; holotype comprising ca 4 whorls (apex missing), $9.3 \mathrm{~mm}$ high, $9.7 \mathrm{~mm}$ wide; suture impressed; whorls slightly convex and slightly shouldered; whorls embrace at periphery so that periphery is at suture; base convex with evenly rounded transition to whorl face; whorls ornamented with evenly spaced distinct spiral cords; distance between cords about twice as wide as cords; cords have approximately same strength; whorls also ornamented with numerous collabral, densely spaced, slightly prosocline axial threads; intersections of spiral cords and axial threads slightly nodular; base shallowly convex, anomphalous, ornamented with up to 10 strong spiral cords and a smooth circumumbilical area; aperture approximately as high as wide; outer and inner 
lip convex, parietal lip concave; aperture acute adapically.

Remarks. - Yunnania meridionalis Mansuy, 1914b from the Permian Productus Limestone of Cambodia is similar to Yunnania pulchra sp. nov. but $Y$. meridionalis has more convex whorls and the axial ribs are not sharp and thread-like but broad and low - Mansuy (1914b) described them as "ondulations transverses", i.e., transverse undulations. Moreover, the spiral cords are stronger in Yunnania meridionalis. The illustration of Yunnania meridionalis given by Delpey (1941) resembles the present specimens in shape but especially the nature of the axial ornament cannot be inferred from this illustration. The illustration of the specimen from the Permian of Malaysia determined as Yunnania meridionalis by Batten (1972) seems to be much more high-spired than $Y$. meridionalis and Yunnania pulchra sp. nov. so that it is not clear whether this specimen really represents $Y$. meridionalis. Other gastropod species assigned to Yunnania generally lack axial ornament.

Family Trochidae Rafinesque, 1815

\section{Genus Anticonulus Cossmann, 1918}

Type species. - Trochus mariae d'Orbigny, 1853, Early Jurassic, France.

Anticonulus? sp.

Figure 17A, B

2014 Pleurotomarioid indet. - Ketwetsuriya et al., p. 140, pl. 1, fig. 1 .

Material. - One specimen, SNSB-BSPG 2014 XI 8.

Description. - Shell acutely conical, small, comprising ca 9 whorls (apex missing), $5.8 \mathrm{~mm}$ high, $3.8 \mathrm{~mm}$ wide; flanks straight; whorl face straight with periphery at transition to base; suture shallow; transition to base markedly angular with a protruding edge; base flat, slightly conical, smooths.

Remarks. - This small conical shell resembles the Mesozoic (Triassic/Jurassic) genus Anticonulus.

\section{Genus Coeloconulus Nützel, 2012 (in Nützel \& Nakazawa)}

Type species. - Coeloconulus panae Nützel, 2012 (in Nützel \& Nakazawa), Middle Permian, Japan.

Remarks. - When Nützel (in Nützel \& Nakazawa 2012) introduced Coeloconulus, he did not differentiate it from the similar Triassic genus Callotrochus Kutassy in Wenz, 1938 (see Szabó 2011). In contrast to Coeloconulus, Callotrochus has a distinctly conical base and thus, the shell as a whole is biconical. Moreover, Callotrochus is much larger.

\section{Coeloconulus panae Nützel, 2012 (in Nützel \& Nakazawa) Figure 17D-F}

Material. - One specimen, SNSB-BSPG 2014 XI 109.

Remarks. - This tiny conical, coeloconoid and phaneromphalous shell is obviously identical with Coeloconulus panae as reported from the Middle Permian Akasaka Limestone from Japan (Nützel \& Nakazawa 2012) although it is much larger and has a more convex base.

\section{Genus Eocalliostoma Haas, 1953}

Type species. - Calliostoma interruptum Cox, 1949, Late Triassic, Peru.

\section{Eocalliostoma sp.}

Figure 17C

Material. - One specimen, SNSB-BSPG 2014 XI 81.

Remarks. - A single acutely trochiform shell (ca 4.5 whorls, $2.7 \mathrm{~mm}$ high, 1.8 wide) with straight and slightly prosocline axial ribs that do not continue onto the base represents a distinct species in this collection. It resembles the Triassic genus Eocalliostoma Haas, 1953 (see also Knight et al. 1960, Nützel \& Erwin 2004). The present specimen also resembles juvenile specimens of the caenogastropod Palaeostylus lateapicatus Nützel, 2012 (in Nützel \& Nakazawa 2012, p. 149, fig. 23o) from the Permian of the Akasaka Limestone, Japan but the latter species has lower whorls and orthocline axial ribs.

Family Microdomatidae Wenz, 1938

\section{Genus Microdoma Meek \& Worthen, 1866}

Type species. - Microdoma conicum Meek \& Worthen, 1866; USA, Carboniferous.

Microdoma carinata sp. nov.

Figure 18

2014 Babylonites? sp.; Ketwetsuriya et al., p. 142, pl. 2, figs $\mathrm{f}-\mathrm{h}$. 
2014 Euconodoma sp.; Ketwetsuriya et al., p. 142, pl. 2, fig. i.

Locus typicus. - Khao Noi hill, Takhli district, Southeast of Nakhon Sawan province, ca $80 \mathrm{~km}$ south of Nakhon Sawan City, Northern Thailand, $15^{\circ} 18^{\prime} 51.801^{\prime \prime} \mathrm{N}$, $100^{\circ} 26^{\prime} 30.358^{\prime \prime} \mathrm{E}$ (Fig. 1).

Stratum typicum. - Tak Fa Formation of the Saraburi Group, Middle Permian, Wordian.

Material. - Holotype SNSB-BSPG 2014 XI 47, paratypes 2014 XI 11, 18, 19, 35, 36, 62, CUMZ 7011, 7012.

Etymology. - For the angular transition from whorl face to base.

Description. - Shell high-spired trochiform, conical with an apical angle of 50-60 ; holotype consisting of about six whorls, $10.6 \mathrm{~mm}$ high, $7 \mathrm{~mm}$ wide; largest specimen (SNSB-BSPG 2014 XI 62) comprising about 5 whorls (apex missing), $12.0 \mathrm{~mm}$ high, $8.3 \mathrm{~mm}$ wide; sutures distinct; flanks straight; whorl face straight to very slightly convex with narrow adapical shoulder in some specimens; whorls largely smooth except of weak reticulate ornament of collabral axial ribs and spiral cords with nodular intersection on early teleoconch whorls; growth lines straight, prosocline; pronounced carina with spiral cord present low on the whorls, emerging from abapical suture, fully exposed on last whorl forming the periphery and angular transition to base of whorls; last part of last whorl somewhat deflected so that carina becomes fully exposed; base convex with pseudo-umbilicus formed by twisted inner lip of aperture; aperture subcircular, somewhat higher than wide; columellar lip slightly twisted forming a fold.

Remarks. - Microdoma carinata sp. nov. resembles the Pennsylvanian type species of Microdoma, Microdoma conicum Meek \& Worthen, 1866. However, Microdoma conicum has rather strong nodes as teleoconch ornament and lacks a twisted inner lip. Some of the Carboniferous Russian species assigned to Microdoma by Mazaev (1997) resemble Microdoma carinata sp. nov. but these species have much stronger nodes or ribs at the suture. Anematina permiana (Yakowlew, 1899) as reported by Mazaev (1997) from the Late Carboniferous of the Russian Platform resembles Microdoma carinata sp. nov. but lacks the strong basal carination. Euconodoma gavinae Kues, 1990, type species of the genus Euconodoma Kues, 1990, from the Pennsylvanian of New Mexico is similar but Euconodoma has strong nodes at the basal angulation and lacks the twisted inner lip of the aperture. Euconodoma was considered to represent a synonym of Microdoma by Batten

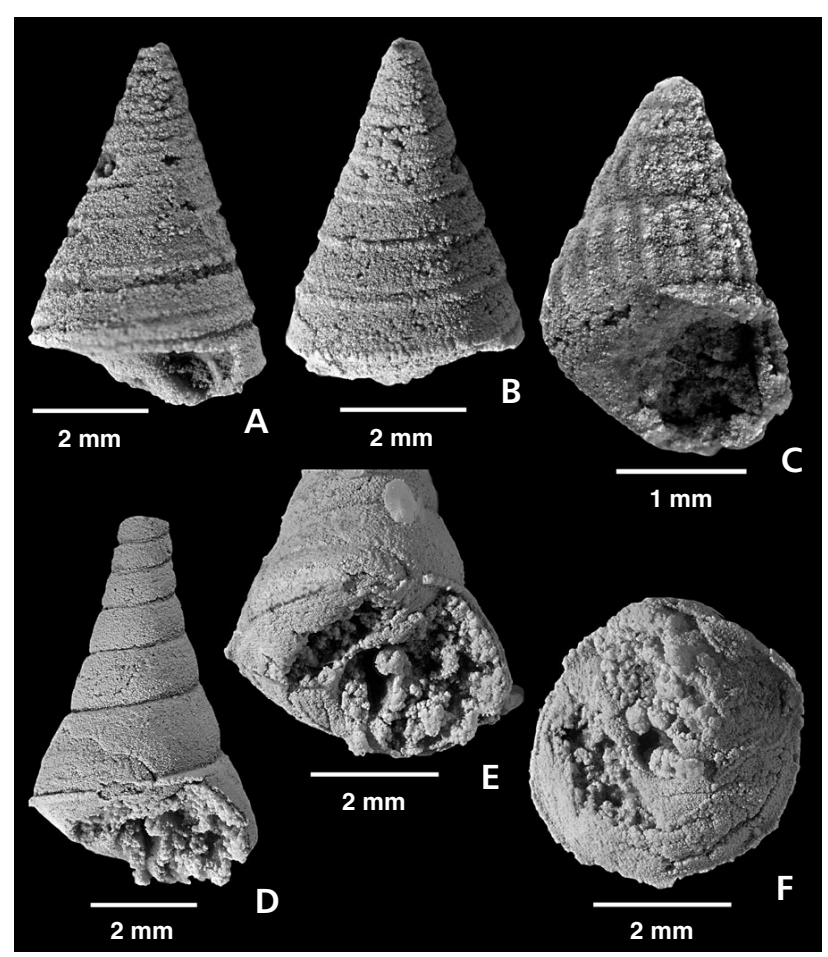

Figure 17. A, B - Anticonulus? sp., SNSB-BSPG 2014 XI 8. • C Eocalliostoma sp., SNSB-BSPG 2014 XI 81. • D-F - Coeloconulus panae Nützel, 2012, SNSB-BSPG 2014 XI 109.

(1995). However, it seems possible that Euconodoma represents a distinct genus.

Subclass Neritimorpha Koken, 1896

Order Cycloneritimorpha Frýda, 1998

Superfamily Naticopsoidea Waagen, 1880

Family Naticopsidae Waagen, 1880

\section{Genus Naticopsis McCoy, 1844}

Type species. - Natica ampliata Phillips, 1836, Carboniferous, Ireland.

\section{Naticopsis spp.}

Figure 19A-I

2014 Naticopsis sp.; Ketwetsuriya et al., p. 144, pl. 2, fig. $k$.

Material. - Six specimens, SNSB-BSPG 2014 XI 57, 66, $68,72,7995$.

Remarks. - Several naticiform, low spired, smooth shells, all smaller $10 \mathrm{~mm}$ are present in this collection representing probably two to three species of the wide-spread and late Palaeozoic genus Naticopsis. The preservation of the 


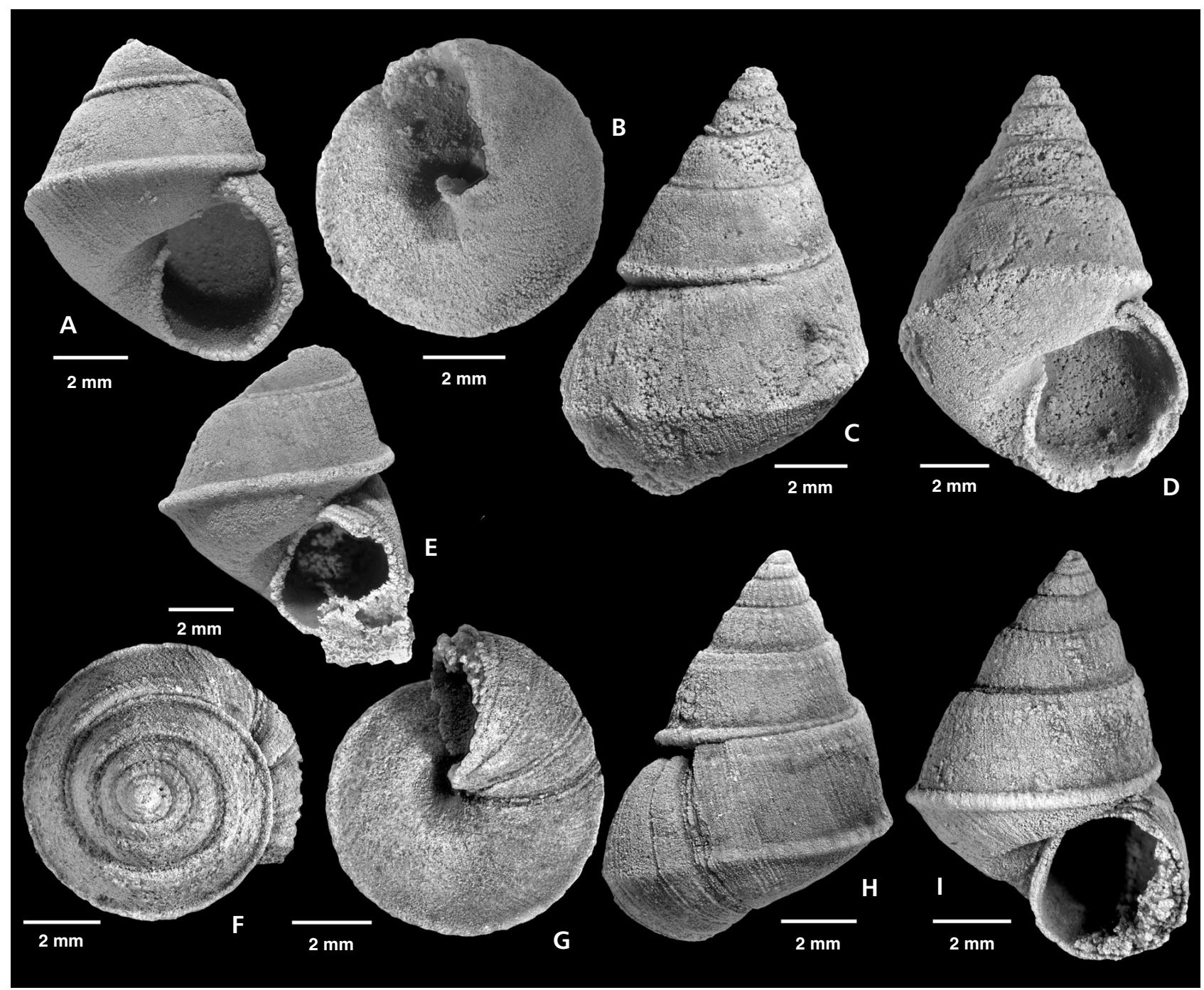

Figure 18. Microdoma carinata sp. nov. • A, B - paratype, SNSB-BSPG 2014 XI 19. • C, D - paratype, SNSB-BSPG 2014 XI 62. • E - paratype, SNSB-BSPG 2014 XI 11. • G-I - holotype, SNSB-BSPG 2014 XI 47.

specimens (especially the apertures) is not sufficient for identification.

Family Trachyspiridae Nützel, Frýda, Yancey \& Anderson, 2007

\section{Genus Trachydomia Meek \& Worthen, 1866}

Type species. - Naticopsis nodosa Meek \& Worthen, 1861, Carboniferous, USA.

\section{Trachydomia takhliensis sp. nov.}

Figure 19J-M

2014 Trachydomia sp.; Ketwetsuriya et al., p. 144, pl. 2, fig. j.
Locus typicus. - Khao Noi hill, Takhli district, Southeast of Nakhon Sawan province, $c a 80 \mathrm{~km}$ south of Nakhon Sawan City, Northern Thailand, $15^{\circ} 18^{\prime} 51.801^{\prime \prime} \mathrm{N}$, $100^{\circ} 26^{\prime} 30.358^{\prime \prime} \mathrm{E}$ (Fig. 1).

Stratum typicum. - Tak Fa Formation of the Saraburi Group, Middle Permian, Wordian.

Material. - Holotype: SNSB-BSPG 2014 XI 41; paratypes SNSB-BSPG 2014 XI 37, CUMZ 7013, 7014.

Etymology. - After the district of Takhli where the species occurs.

Description. - Shell naticiform to turbiniform; holotype $11.7 \mathrm{~mm}$ high, $9.8 \mathrm{~mm}$ wide; largest specimen (SNSB-BSPG 2014 XI 87) $30 \mathrm{~mm}$ high (apex missing), 


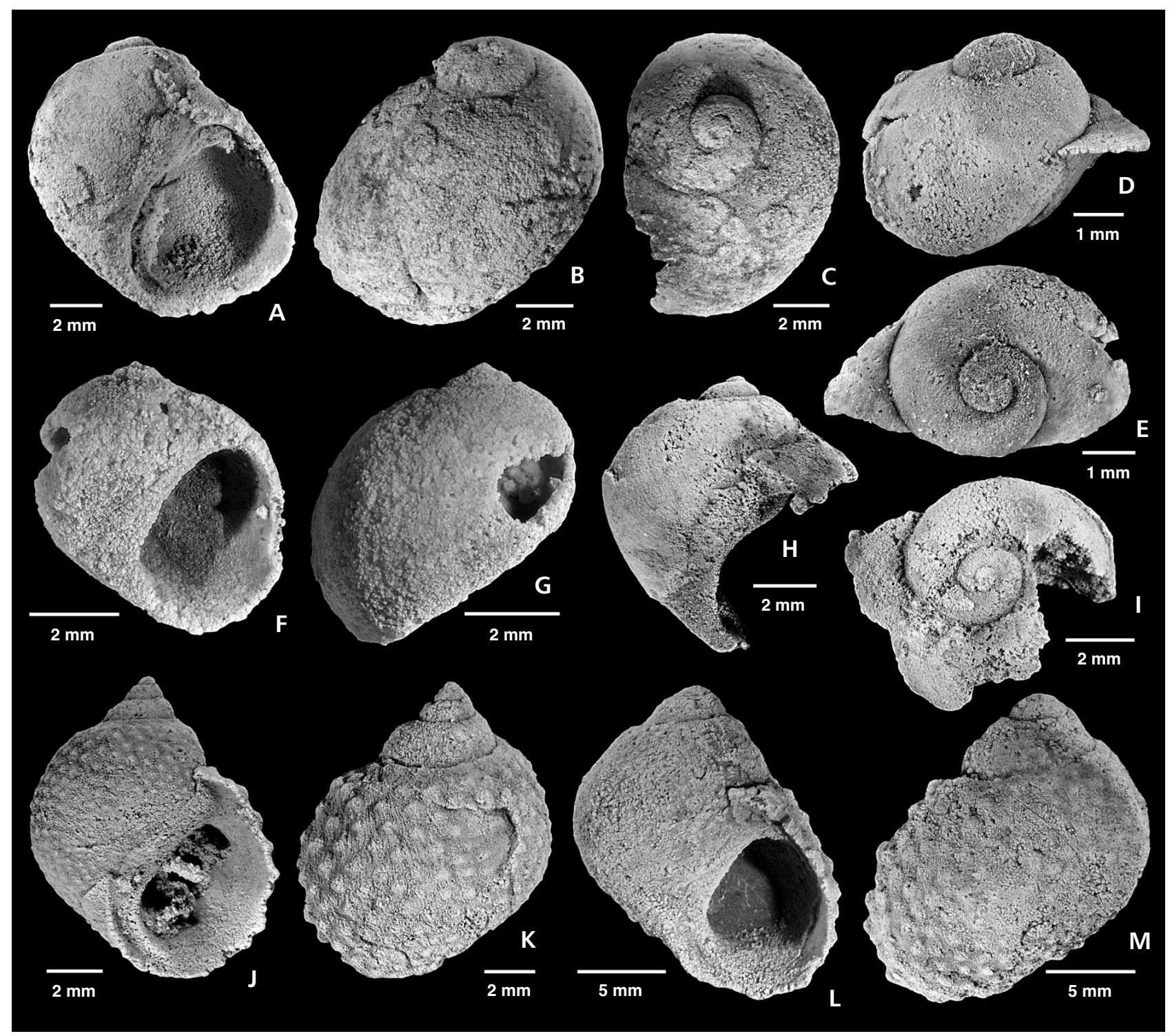

Figure 19. A-C-Naticopsis sp., SNSB-BSPG 2014 XI 95. •D, E-Naticopsis sp., SNSB-BSPG 2014 XI 72. • F, G-Naticopsis sp., SNSB-BSPG 2014 XI 57. • H, I - Naticopsis sp., SNSB-BSPG 2014 XI 66. - J, K - Trachydomia takhliensis sp. nov., holotype, SNSB-BSPG 2014 XI 41. • L, M - Trachydomia takhliensis sp. nov., paratype, SNSB-BSPG 2014 XI 37.

$31 \mathrm{~mm}$ wide; spire acute distinctly elevated; body whorl much higher than spire with height about $85 \%$ of total height; whorls round, convex with a narrow subsutural ramp; whorls embracing at periphery; whorls ornamented with distinct nodes which are strongest on the body whorl; suture distinct; base round, convex with evenly rounded transition to base; growth lines prosocline; aperture D-shape with thickened outer lip and parietal inductura; columellar lip straight, oblique to shell axis, widened with a crescent-shaped furrow; outer lip evenly convex; base anomphalous, convex.

Remarks. - Trachydomia takhliensis sp. nov. is a typical representative of the genus Trachydomia. Trachydomia dussaulti Mansuy, 1913 from the Permian Productus Limestone of Laos is similar in shape but has finer and denser nodes. Trachydomia dussaulti has also been reported from the Permian of Perak, Malaysia by Batten (1979) and the specimen he illustrated has much finer nodes which are arranged in prosocline lines. Moreover, its ramp is less pronounced. Trachydomia gobbeti Batten, 1979 from the Permian of Perak, Malaysia has nodes which are strictly arranged in spiral lines and the adapical nodes are much stronger than the abapical ones. Trachydomia imbricata Batten, 1979 and T. gemmulata Batten, 1979, both from the Permian of Perak, Malaysia differ strongly from Trachydomia takhliensis sp. nov. in shape and ornament. Trachydomia cf. nodosa (Meek \& Worthen, 1866) from the Middle 


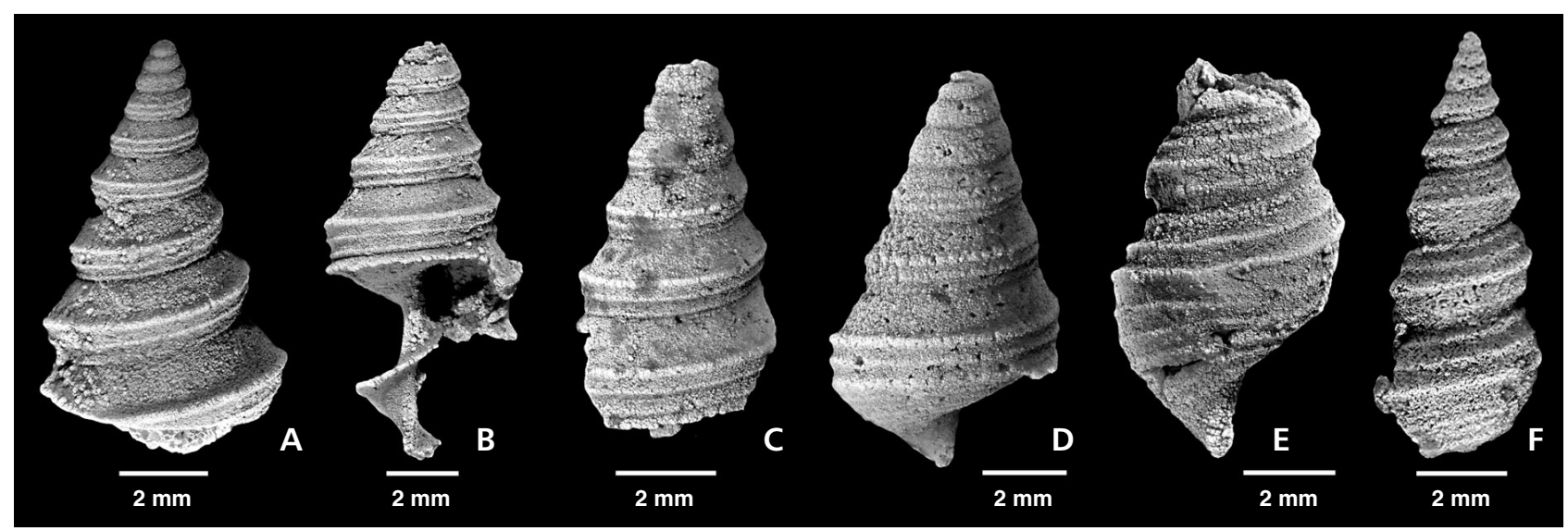

Figure 20. A - Goniasma tricarinata sp. nov., holotype, SNSB-BSPG 2014 XI 45. • B - Goniasma tricarinata sp. nov., paratype, CUMZ 7015 . $・$ C Goniasma tricarinata sp. nov., paratype, CUMZ 7016. • D - Goniasma tricarinata sp. nov., paratype, SNSB-BSPG 2014 XI 5. • E - Stegocoelia sp. 1, SNSB-BSPG 2014 XI 80. • F - Stegocoelia sp. 1, SNSB-BSPG 2014 XI 30.

Permian of Japan as reported by Nützel \& Nakazawa (2012) has nodes which are strictly arranged in spiral lines. Trachydomia nodosa, type species of the genus Trachydomia, is broader and has fewer but much coarser nodes. Trachydomia minuta Pan \& Erwin, 2002 from the Late Permian of China is much more high-spired. Trachydomia deprati Mansuy, 1914b from the Permian Productus Limestone of Cambodia is broader and has less convex whorls.

Subclass Caenogastropoda Cox, 1960

Superfamily Orthonematoidea Nützel \& Bandel, 2000

Family Goniasmatidae Nützel \& Bandel, 2000

Subfamily Goniasmatinae Nützel \& Bandel, 2000

\section{Genus Goniasma Tomlin, 1930}

Type species. - Murchisonia lasallensis Worthen, 1890, Pennsylvanian, USA.

\section{Goniasma tricarinata sp. nov.}

Figure 20A-D

Locus typicus. - Khao Noi hill, Takhli district, Southeast of Nakhon Sawan province, $c a 80 \mathrm{~km}$ south of Nakhon Sawan City, Northern Thailand, $15^{\circ} 18^{\prime} 51.801^{\prime \prime} \mathrm{N}$, $100^{\circ} 26^{\prime} 30.358^{\prime \prime}$ E (Fig. 1).

Stratum typicum. - Tak Fa Formation of the Saraburi Group, Middle Permian, Wordian.

Etymology. - Latin, with three carinae (spiral cords).

Material. - Holotype: SNSB-BSPG 2014 XI 45; paratypes: SNSB-BSPG 2014 XI 5, CUMZ 7015, 7016.
Description. - Shell high-spired; holotype comprises about 9 whorls, $9.5 \mathrm{~mm}$ high, $5.6 \mathrm{~mm}$ wide; suture distinct; whorls angulated at about mid-whorl with a broad, steep subsutural ramp; whorl face vertical, parallel to shell axis below angulation; abapical portion of whorls with three equally spaced prominent spiral cords; strongest spiral cord located at mid-whorl at angulation forming periphery; ramp largely smooth, straight with very weak spiral cord near the suture; base slightly rounded.

Remarks. - The present specimens resemble the Late Carboniferous type species of Goniasma, Goniasma lasallensis Worthen, 1890 (see also Mazaev 2011, p. 1564, pl. 1, figs 9-13) but in that species, the angulation is lower on the whorls and it lacks the three strong spiral cords low on the whorls. Goniasma fortecarinata Nützel, 2012 (in Nützel \& Nakazawa) from the Middle Permian Akasaka Limestone, Japan is similar but the upper two spiral cords are much stronger than the abapical one.

\section{Genus Stegocoelia Donald, 1889}

Type species. - Murchisonia (Stegocoelia) compacta Donald, 1889, Early Carboniferous, Scotland.

Remarks. - The subgenus Hypergonia Donald, 1892 has been considered to represent a synonym of Stegocoelia by Mazaev (2001, 2011).

\section{Stegocoelia sp. 1}

Figure 20E, F

Material. - Two specimens, SNSB-BSPG 2014 XI 30, 80. 
Remarks. - These small, high-spired slender murchisoniform gastropods have a prominent ornament of four spiral cords on whorl face. The whorls are distinctly convex and somewhat angulated. They resemble several Late Palaeozoic species, for instance some species from the Carboniferous of Russia as described by Mazaev (2001). Murchisonia dussaulti Mansuy, 1914b from the Productus Limestone of Cambodia could be similar but is too poorly known for a meaningful comparison (see also Delpey 1941, fig. 42). Stegocoelia akasakaensis Nützel, 2012 from the Middle Permian Akasaka Limestone of Japan is similar but this species is much smaller and the spiral cords have a different position (Nützel \& Nakazawa 2012).

\section{Stegocoelia sp. 2}

Figure 21C

2014 Stegocoelia? sp. 2; Ketwetsuriya et al., p. 145, pl. 2, fig. p.

Material. - One specimen, SNSB-BSPG 2014 XI 94.

Description. - Shell small, high-spired, slender, comprising about 9 whorls, $7.2 \mathrm{~mm}$ high, $2.3 \mathrm{~mm}$ wide; suture shallow; whorl face straight; whorls ornamented with four distinct spiral cords; adapical spiral cord in subsutural position; second spiral cord somewhat weaker, situated above mid-whorl; third spiral cord strongest, forming periphery, low on the whorl; fourth spiral cord weak, emerging from abapical suture; base flat with angular transition to whorl face.

Remarks. - This shell is poorly preserved but clearly represents a distinct species in the present collection. Similar shells, poorly preserved as well, were reported by Kulas \& Batten (1997) as Stegocoelia (Hypergonia) percostata (Girty, 1939) and Stegocoelia (Hypergonia?) sp. from the Permian of Wyoming. Stegocoelia turabievoensis Mazaev, 2001 from the Carboniferous is also similar but much larger.

Family Orthonematidae Nützel \& Bandel, 2000

\section{Genus Orthonema Meek \& Worthen, 1862}

Type species. - Eunema (?) salteri Meek \& Worthen, 1860, Carboniferous, USA.

\section{Orthonema sp.}

Figure 21A, B

Material. - One specimen, SNSB-BSPG 2014 XI 53.

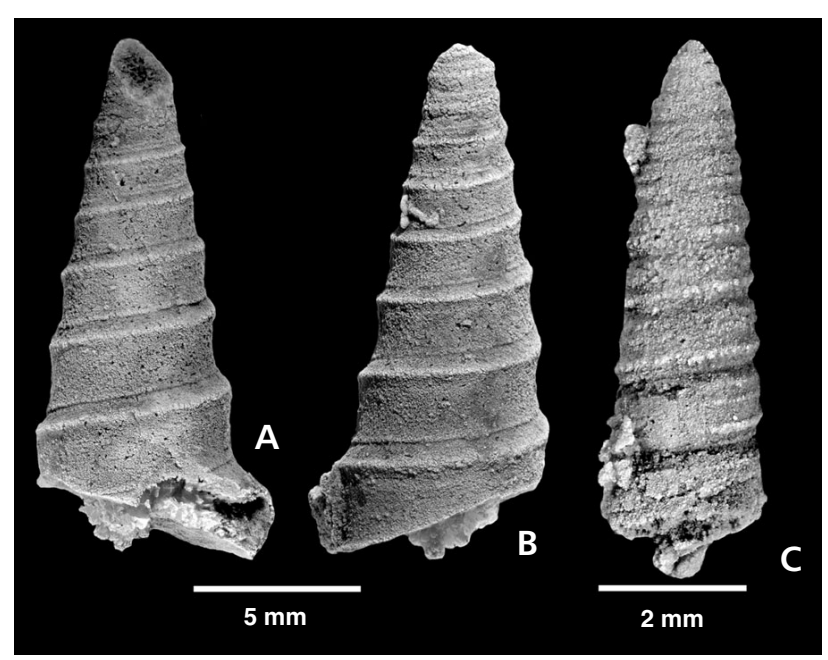

Figure 21. A, B - Orthonema sp., SNSB-BSPG 2014 XI 53. • C Stegocoelia sp. 2, SNSB-BSPG 2014 XI 94.

Description. - Shell high-spired, slender, ca 8 whorl with apex missing, $16 \mathrm{~mm}$ high, $7 \mathrm{~mm}$ wide; suture shallow but distinct; whorls largely smooth, ornamented with a distinct, sharp subsutural spiral cord bordering a narrow ramp; abapical spiral lira emerging just at suture; whorl face concave.

Remarks. - This specimen resembles species of the genus Orthonema as, for instance, reported from the Carboniferous of Russia (Mazaev 2002) and the Permian of the Southwestern USA (Erwin 1988a).

\section{Genus Protostylus Mansuy, 1914a}

Type species. - Protostylus lantenoisi Mansuy, 1914a, Carboniferous, SE Asia.

Remarks. - Based on Middle Permian high-spired, smooth gastropods, Nützel \& Nakazawa (2012) discussed the poorly known genus Protostylus. The type species as well as the other species assigned to this genus are poorly preserved and thus, identity and systematics of this genus remain uncertain. Batten (1995) placed Protostylus in Procerithiidae based on the presence of an anterior siphonal canal. Nützel in Nützel \& Nakazawa (2012) placed Protostylus tentatively in the family Orthonematidae.

\section{Protostylus sp.}

Figure $23 \mathrm{~A}-\mathrm{F}$

Material. - Five specimens, SNSB-BSPG 2014 XI 40, 56, 74, 99, 114. 
Description. - Shell high-spired; largest specimen consists of about 10 whorls, $20 \mathrm{~mm}$ high, $6.8 \mathrm{~mm}$ wide; sutures distinct; whorls low, slightly convex with periphery somewhat below mid-whorl, embracing low on previous whorl; whorls smooth; base rounded, convex; aperture subovate, somewhat higher than wide.

Remarks. - The present specimens resemble Protostylus sp. from the Middle Permian Akasaka Limestone from Japan as reported by Nützel \& Nakazawa (2012). However, the Japanese species is somewhat more slender. The studied specimens show a narrow spiral breakage high on the whorls. If this reflects the presence of a selenizone or sinus, this species could be related to genera like Altadema Kues, 2002 or Kazanella Mazaev, 2015. Streptacis? complanata Hoare, Sturgeon \& Anderson, 1997 from the Pennsylvanian of the USA resembles Protostylus sp. and could be a representative of the genus Protostylus rather than Streptacis - the latter is usually more slender. The Chinese Carboniferous species Protostylus lantenoisi Mansuy, 1914a and P. dussualti Mansuy, 1914a closely resembles the present species as far as can be inferred from the original illustrations. Protostylus lantenoisi has also been reported from the Permian of Perak, Malaysia by Batten (1985).

Superfamily Soleniscoidea Knight, 1931a

Family Soleniscidae Knight, 1931a

Subfamily Soleniscinae Knight, 1931a

\section{Genus Soleniscus Meek \& Worthen, 1861}

Type species. - Soleniscus typicus Meek \& Worthen, 1861, Carboniferous, USA.

\section{Soleniscus sp.}

Figure 22A, B

Material. - One specimen, SNSB-BSPG 2014 XI 120.

Remarks. - This relatively slender, fusiform, smooth soleniscid shell (13 mm high, $4 \mathrm{~mm}$ wide) shows a distinct columellar fold. Shells like this have been repeatedly reported from the Late Palaeozoic of the world for instance Soleniscus variabilis Erwin, 1988b from the Permian of the USA is quite similar (see also Nützel et al. 2000, Batten 1995).

\section{Genus Strobeus de Koninck, 1881}

Type species. - Strobeus ventricosus de Koninck, 1881, Mississippian, Belgium.

\section{Strobeus sp.}

Figure 22C, D

Material. - One specimen, SNSB-BSPG 2014 XI 119.

Remarks. - This broad, smooth incomplete soleniscid shell (7.3 mm high, $5.1 \mathrm{~mm}$ wide) shows a distinct columellar fold. Strobeus is wide-spread and diverse in Late Palaeozoic deposits for instance Strobeus girtyi Erwin, 1988b from the Permian of the USA and the Late Permian Strobeus dongluoensis (Pan \& Yu, 1993) (see also Nützel \& Nakazawa 2012) are similar. However, more and better-preserved specimens are needed for species identification.

\section{Genus Cylindritopsis Gemmellaro, 1890}

Type species. - Cylindritopsis ovalis Gemmellaro, 1890, Permian, Italy.

\section{Cylindritopsis spheroides Erwin, 1988b}

Figure 22E-G

1988b Cylindritopsis spheroides sp. nov.; Erwin, p. 65, fig. 4.1-4.4.

Material. - One specimen, SNSB-BSPG 2014 XI 52.

Description. - Shell spherical, oval, low-spired, $5.1 \mathrm{~mm}$ high, $5.2 \mathrm{~mm}$ wide; spire small; whorls smooth, convex, inflated; suture indistinct; aperture crescent shaped, acute adapically, rounded ababically; aperture with two strong columellar folds of equal strength with perpendicular orientation against inner lip; parietal callus present; base evenly rounded, anomphalous.

Remarks. - The present specimen closely resembles Cylindritopsis spheroides Erwin, 1988b from the Permian of the southwestern United States. Cylindritopsis spheroides could also represent the neritid genus Oncochilus Pethö, 1882 (in Zittel) which is based on a Jurassic type species. In fact, Oncochilus matches Cylindritopsis spheroides better than the usually more high-spired Cylindritopsis. Yochelson \& Saunders (1967) listed two Permian species assigned to Oncochilus and stated that the genus was clearly present in the Late Palaeozoic.

Family Meekospiridae Knight, 1956

Genus Meekospira Ulrich, in Ulrich \& Scofield, 1897

Type species. - Eulima peracuta Meek \& Worthen, 1861, Carboniferous, USA. 


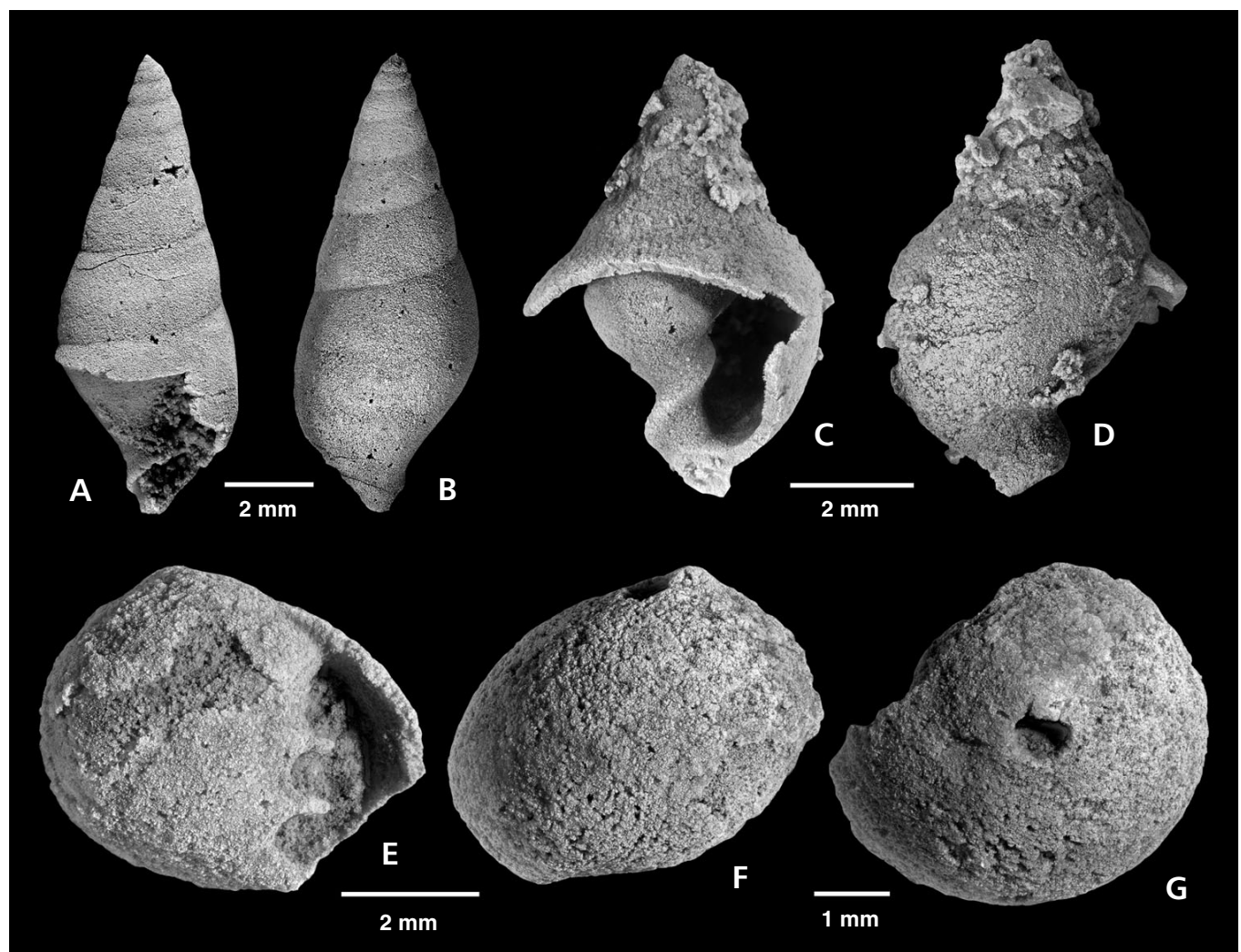

Figure 22. A, B - Soleniscus sp., SNSB-BSPG 2014 XI 120. • C, D - Strobeus? sp., SNSB-BSPG 2014 XI 119. • E-G - Cylindritopsis spheroides Erwin, 1988b, SNSB-BSPG 2014 XI 52.

\section{Meekospira sp.}

Figure 23G

2014 Meekospira sp.; Ketwetsuriya et al., p. 144, pl. 2, fig. m.

Material. - One specimen, SNSB-BSPG 2014 XI 7.

Remarks. - This single slender fusiform shell $(7.8 \mathrm{~mm}$ high, $5.8 \mathrm{~mm}$ high) with straight flanks and slightly convex, smooth whorls is a typical representative of the genus Meekospira which is widespread and diverse in the Late Palaeozoic (e.g., Knight 1932, Erwin 1988b, Nützel et al. 2000). Meekospira melanoides and M. ligonensis, both described by Batten (1985) from the Permian of Perak, Malaysia are more slender and have higher whorls.

\section{Genus Ceraunocochlis Knight, 1931a}

Type species. - Ceraunocochlis fulminula Knight, 1931a, Pennsylvanian, USA.

\section{Ceraunocochlis sp.}

Figure $23 \mathrm{H}$

Material. - One specimen, SNSB-BSPG 2014 XI 78.
Description. - Cigar-shaped shell, slender, high-spired, asymmetrical, with convex flank opposed to a to slightly concave flank; shell comprising ca 7 whorls, $5.1 \mathrm{~mm}$ high, $1.4 \mathrm{~mm}$ wide; last whorl incomplete but seemingly slightly constricted; whorls high, smooth; suture obscure, very shallow; whorl face almost straight; aperture not preserved.

Remarks. - The generic assignment of this specimen is beyond doubt. It resembles Ceraunocochlis fulminula Knight, 1931a from the Pennsylvanian of the USA and Ceraunocochlis sp. as reported by Nützel \& Nakazawa (2012) from the Middle Permian Akasaka Limestone, Japan.

\section{Genus Cambodgia Mansuy, 1914b}

Type species. - Cambodgia sinsistrorsa Mansuy, 1914b, Permian, Cambodia.

Cambodgia acuminata sp. nov.

Figure 24A-C

2014 Cambodgia cf. sinistrorsa Mansuy, 1914b. - Ketwetsuriya et al., p. 144, pl. 2, fig. 1. 
Locus typicus. - Khao Noi hill, Takhli district, Southeast of Nakhon Sawan province, ca $80 \mathrm{~km}$ south of Nakhon Sawan City, Northern Thailand, $15^{\circ} 18^{\prime} 51.801^{\prime \prime} \mathrm{N}$, $100^{\circ} 26^{\prime} 30.358^{\prime \prime} \mathrm{E}$ (Fig. 1).

Stratum typicum. - Tak Fa Formation of the Saraburi Group, Middle Permian, Wordian.

Material. - Four specimens, holotype: SNSB-BSPG 2014 XI 98, paratypes: SNSB-BSPG 2014 XI 54, 117, CUMZ 7017.

Etymology. - Latin needle-shaped, acute.

Description. - Shell sinistral, small, high-spired, very slender with an apical angel of less than $30^{\circ}$ and numerous whorls; largest specimen comprising 9 whorls with apex missing, $12.7 \mathrm{~mm}$ high, $3.3 \mathrm{~mm}$ wide; holotype comprising ca 14 whorls, $7.4 \mathrm{~mm}$ high, $4.0 \mathrm{~mm}$ wide; early shell slightly coeloconoid; whorls smooth, weakly convex; sutures shallow but distinct; aperture unknown.

Remarks. - The sinistral species Cambodgia acuminata sp. nov. is extremely needle-shaped. It resembles Cambodgia sinistrorsa Mansuy, 1914b from the Permian Productus Limestone of Cambodia. However, Cambodgia acuminata sp. nov. is much more slender. The sinistral, needle-shaped species Methorthonema sinistrale Erwin, 1988a from the Early Permian of the Soutwestern USA is more pronouncedly coeloconoid in the early whorls and later whorls are straight-sided so that the teleoconch is almost cylindrical which is not the case in Cambodgia acuminata sp. nov.

Family Palaeostylidae Wenz, 1938

\section{Genus Trepsipleura Kues, 2002}

Type species. - Trepsipleura chordanodosa Kues, 2002, Pennsylvanian, USA.

Remarks. - Kues (2002) discussed the assignment of Trepsipleura and placed it in Pseudozygopleuridae Knight, 1930 but also discussed a possible assignment to Palaeozygopleuridae. We think that an assignment to Palaeostylidae is the better choice because of the low whorls and the lack of the typical pseudozygopleurid larval shell as far as it is known [shown for Palaeozygopleura? perversa (Knight, 1930 ) by Nützel 1998]. Synonymy of the three species $P a$ laeozygopleura? perversa (Knight, 1930), Palaeostylus? (Pseudozygopleura) bella Carew, 1980 and Trepsipleura chordanodosa Kues, 2002 seems to be possible. The sinistral species Palaeozygopleura retroflexa Licharev, 1968 is distinct by having a denser ribbing.
Trepsipleura chordanodosa Kues, 2002

Figure 24D, E

2014 Palaeostylus sp.; Ketwetsuriya et al., p. 144, pl. 2, fig. $\mathrm{n}$.

Material. - Two specimens, SNSB-BSPG 2014 XI 1, 112.

Description. - Shell sinistral, high-spired, cyrtoconoid; larger specimen is $12.9 \mathrm{~mm}$ high, $3.7 \mathrm{~mm}$ wide; whorls low, rounded quadrangular in transverse section; whorls slightly convex; sutures distinct; whorls ornamented with strong, straight to slightly opisthocyrt, broad, rounded axial ribs, numbering about 12-16 per whorl presumably reduced on the last whorls; aperture with indistinct siphonal notch.

Remarks. - The present specimens closely resemble the Middle Pennsylvanian Trepsipleura chordanodosa from West Texas so that the present material is identified with this species despite the considerable difference in age. Other similar sinistral species with zygopleuroid habitus are $\mathrm{Pa}$ laeozygopleura? perversa (Knight, 1930) from the Pennsylvanian of the USA (see Nützel 1998) and Palaeostylus? (Pseudozygopleura) bella Carew, 1980 from the Pennsylvanian of Texas.

Superfamily Zygopleuroidea Wenz, 1938

Family Pseudozygopleuridae Knight, 1930

\section{Genus Pseudozygopleura Knight, 1930}

\section{Pseudozygopleura? sp.}

Figure 24F

Material. - One specimen, SNSB-BSPG 2014 XI 55.

Description. - Shell high-spired to fusiform, comprising $\mathrm{ca}$ 6 whorls, $12.6 \mathrm{~mm}$ high, $5.3 \mathrm{~mm}$ wide; whorls convex with strong axial ribs numbering about 14 to 16 per whorl; ribs round, as wide as interspaces, distinctly prosocline; ribs reduced on last preserved whorl; suture distinct; base rounded, anomphalous.

Remarks. - The present shell with zygopleuroid morphology could represent the diverse Late Palaeozoic gastropod family Pseudozygopleuridae but knowledge of the protoconch is needed for a meaningful taxonomic treatment.

Subclass Heterobranchia Burmeister, 1837

Superfamily Streptacidoidea Knight, 1931b

Family Streptacididae Knight, 1931b 


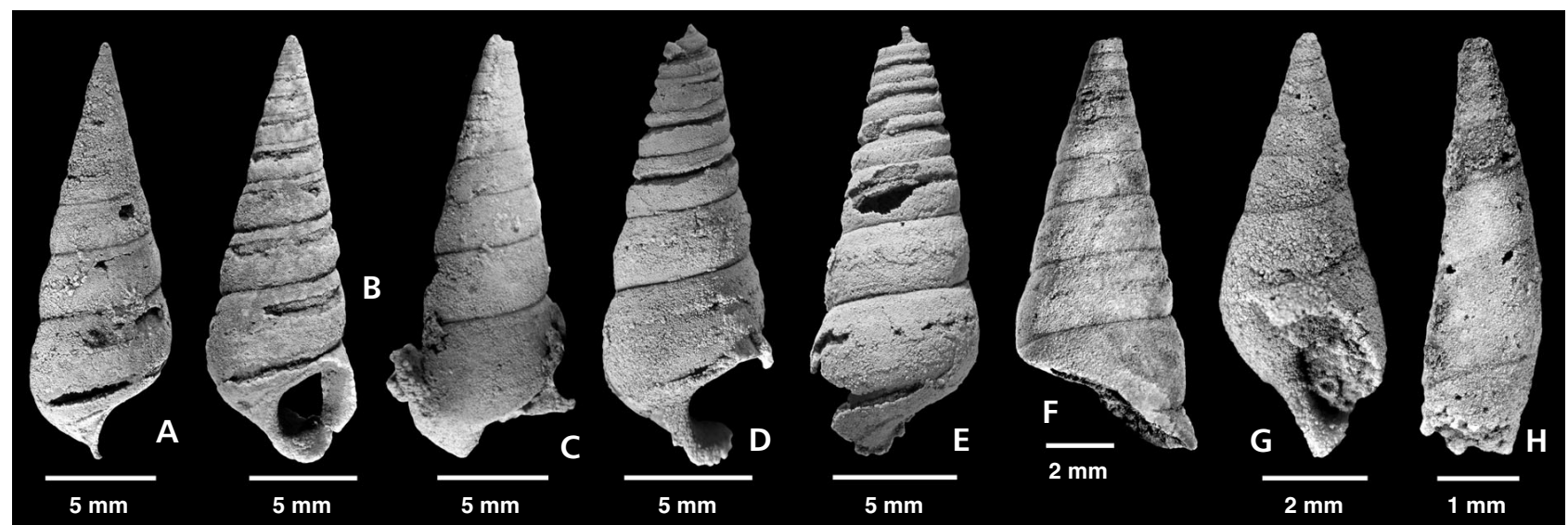

Figure 23. A - Protostylus sp., SNSB-BSPG 2014 XI 40. • B - Protostylus sp., SNSB-BSPG 2014 XI 56. • C - Protostylus sp., SNSB-BSPG 2014 XI 99. D, E - Protostylus sp., SNSB-BSPG 2014 XI 114. • F - Protostylus sp., SNSB-BSPG 2014 XI 74. • G - Meekospira sp., SNSB-BSPG 2014 XI 7. $\bullet$ H - Ceraunocochlis sp., SNSB-BSPG 2014 XI 78.

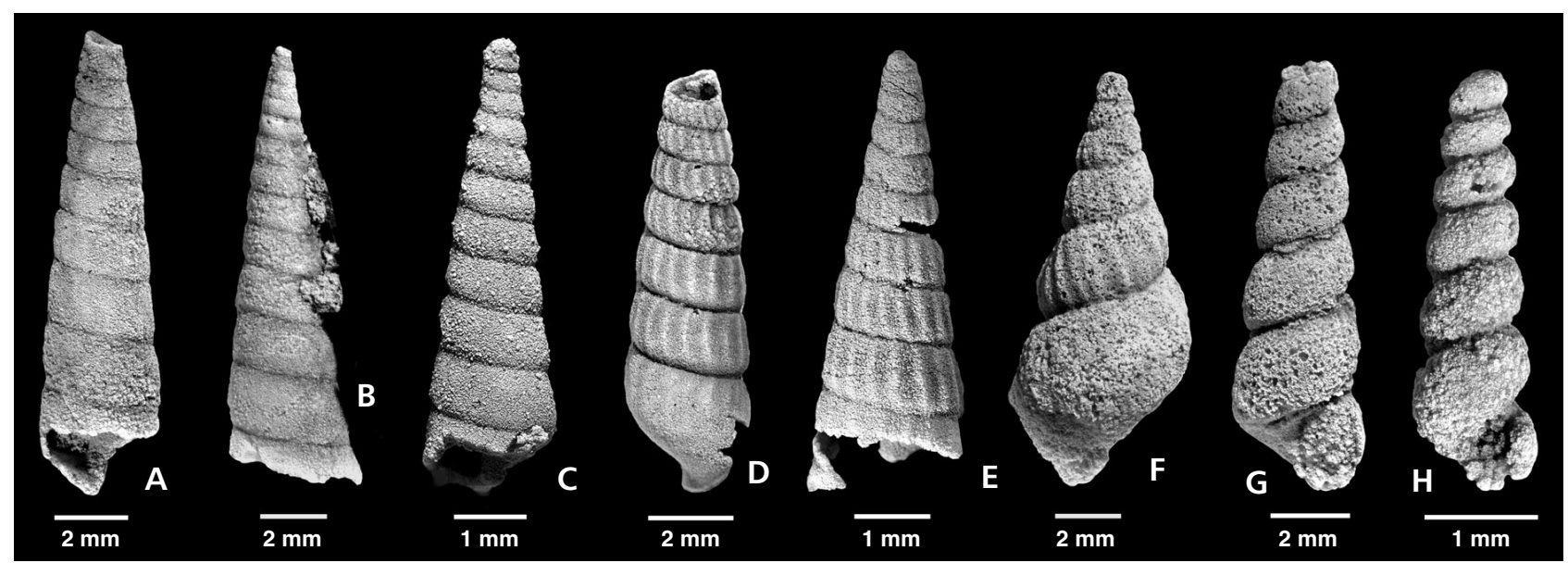

Figure 24. A - Cambodgia acuminata sp. nov., paratype, SNSB-BSPG 2014 XI 54. • B - Cambodgia acuminata sp. nov., holotype, SNSB-BSPG 2014 XI 98. • C - Cambodgia acuminata sp. nov., paratype, SNSB-BSPG 2014 XI 117. • D - Trepsipleura chordanodosa Kues, 2002 , SNSB-BSPG 2014 XI 1. •E - Trepsipleura chordanodosa Kues, 2002, SNSB-BSPG 2014 XI 112. • F - Pseudozygopleura? sp., SNSB-BSPG 2014 XI 55. • G - Streptacis? sp., SNSB-BSPG 2014 XI 51. • H - Streptacis? sp., SNSB-BSPG 2014 XI 71.

\section{Genus Streptacis Meek, 1871}

Type species. - Streptacis whitfieldi Meek, 1871, Carboniferous, USA.

\section{Streptacis? sp.}

Figure 24G, H

Material. - Two specimens, SNSB-BSPG 2014 XI 51, 71.

Description. - Shell high-spired, slender; larger specimen $11.3 \mathrm{~mm}$ high (apex missing), $3.5 \mathrm{~mm}$ wide; whorls smooth, strongly convex; suture impressed; base convex, rounded.

Remarks. - High-spired, small, smooth shells like the present ones have been commonly reported from Late Palaeo- zoic deposits of the world, for instance Streptacis whitfieldi Meek, 1871 from the Carboniferous of the USA and Streptacis orientalis Nützel, 2012 as well as Streptacis? sp. from the Middle Permian Akasaka Limestone of Japan (Nützel \& Nakazawa 2012).

\section{Acknowledgements}

We thank Alexey Mazaev (Moscow) for critically reading an earlier draft of this work. Alex Cook (Brisbane) and Andrzej Kaim (Warszawa) are acknowledged for reviewing this paper. We would also like to thank Felix Schlagintweit (Munich) for helping to identify the algal remains. Visits of the first author to Munich were supported by a Thai government's scholarship for the development and promotion of Science and Technology talents project. 


\section{References}

BANDEL, K. 1988. Repräsentieren die Euomphaloidea eine natürliche Einheit der Gastropoden? Mitteilungen aus dem Geologisch-Paläontologischen Institut der Universität Hamburg 67, 1-33.

BAtTEN, R.L. 1964. Some Permian Gastropoda from Eastern Arizona. American Museum Novitates 2165, 1-16.

Batten, R.L. 1972. Permian gastropods and chitons from Perak, Malaysia. Part 1. Chitons, bellerophontids, euomphalids and pleurotomarians. Bulletin of the American Museum of Natural History 147, 1-44.

Batten, R.L. 1979. Permian gastropods from Perak, Malaysia. Part 2. The trochids, patellids, and neritids. American Museum Novitates 2685, 1-26.

Batten, R.L. 1985. Permian gastropods from Perak, Malaysia. Part 3. The murchisoniids, cerithiids, loxonematids, and subulitids. American Museum Novitates 2829, 1-40.

Batten, R.L. 1989. Permian Gastropoda of the Southwestern United States. 7. Pleurotomariacea: Eotomariidae, Lophospiriidae, Gosseltinidae. American Museum Novitates 2958, $1-64$.

Batten, R.L. 1995. Pennsylvanian (Morrowan) gastropods from the Magdalena Formation of the Hueco Mountains, Texas. American Museum Novitates 3122, 1-46.

Bouchet, P., FrÝda, J., Hausdorf, B., Ponder, W.F., Valdés, Á. \& WARÉN, A. 2005. Working classification of the Gastropoda, 1-397. In Bouchet, P. \& Rocroi, J.-P. (eds) Classification and nomenclator of gastropod families. Malacologia 47.

Bouchet, P., Hausdorf, B., Kaim, A., Kano, Y., Nützel, A., Parkhaev, P., Schrödl, M. \& Strong, E.E. in review. Classification of the Gastropoda. In Bouchet, P. \& Rocroi, J.-P. (eds) Revised classification, nomenclator and typification of gastropod families. Malacologia.

BuRMEISTER, H. 1837. Handbuch der Naturgeschichte, vol. 2., Zoologie, 369-858. Enslin, Berlin.

CARew, J.L. 1980. A new Pennsylvanian pseudozygopleurid gastropod from Texas. Journal of Paleontology 54, 1209-1212.

Chronic, H. 1952. Molluscan Fauna from the Permian Kaibab Formation, Walnut Canon, Arizona. Bulletin of the Geological Society of America 63, 95-166. DOI 10.1130/0016-7606(1952)63[95:MFFTPK]2.0.CO;2

ConRad, T.A. 1842. Observations on the Silurian and Devonian systems of the United States, with description of new organic remains. Academy of Natural Sciences of Philadelphia, Journal 8, 228-280.

Cossmann, M. 1918. Essais de paléoconchologie comparée. Livraison 11.388 pp. The author, Paris.

Cox, L.R. 1949. Moluscos del Triasico superior del Peru (Upper Triassic Mollusca from Peru). Instituto Geologico del Peru Boletin 12, 5-50.

Cox, L.R. 1960. Thoughts on the classification of the Gastropoda. Proceedings of the Malacological Society of London 33, 239-261.

Cumings, E.R. 1906. Gasteropoda, Cephalopoda and Trilobita from the Salem limestone. Indiana Department of Geology and Natural Resources Annual Reports 30, 1335-1375.

Cuvier, G. 1795. Second mémoire sur l'organisation et les rapports des animaux à sang blanc, dans lequel on traite de la structure des Mollusques et de leur division en ordres, lu à la Société d'histoire naturelle de Paris, le 11 Prairial, an III. Magazin Encyclopédique, ou Journal des Sciences, des Lettres et des Arts 2, 433-449.

Delpey, G. 1941. Les Gastéropodes permiens du Cambodge. Journal de Conchyologie 84, 255-278, 345-369.

Dickins, J.M. 1963. Permian pelecypods and gastropods from Western Australia. Bureau of Mineral Resources, Geology and Geophysics Bulletin 63, 1-203.

Donald, J. 1889. Descriptions of new species of Carboniferous gastropods. Quarterly Journal of the Geological Society of London 45, 619-625.

DOI 10.1144/GSL.JGS.1889.045.01-04.39

DonALD, J. 1892. Notes on some new and little known species of Carboniferous Murchisonia. Quarterly Journal of the Geological Society of London 68, 562-575.

DOI 10.1144/GSL.JGS.1892.048.01-04.41

ERwIN, D.H. 1988a. Permian Gastropoda of the Southwestern United States: Cerithiacea, Acteonacea, and Pyramidellacea. Journal of Paleontology 62, 566-575.

ERwin, D.H. 1988b. Permian Gastropoda of the Southwestern United States: Subulitacea. Journal of Paleontology 62, 56-69.

Fleming, J. 1828. A History of British Animals Exhibiting the Descriptive Characters and Systematical Arrangements of the Genera and Species of Quadrupeds, Birds, Reptiles, Fishes, Mollusca and Radiata of the United Kingdom. 565 pp. Bell \& Bradfute, Edinburgh. DOI 10.5962/bhl.title.12859

Gemmellaro, G.G. 1890. La Fauna dei calcari con Fusulina della valle del fiume Sosio nella Provincia di Palermo. Giornale di Science Naturali ed Economiche 20, 97-182.

GiRTY, G.H. 1912. On some invertebrate fossils from the Lykins formation of eastern Colorado. Annals of the New York Academy of Sciences 12, 1-8. DOI 10.1111/j.1749-6632.1912.tb55157.x

GiRTY, G.H. 1915. Fauna of the Wewoka Formation of Oklahoma. Bulletin of the United States Geological Survey 544, $1-353$.

GiRTY, G.H. 1939. Certain pleurotomariid gastropods from the Carboniferous of New Mexico and Texas. Journal of the Washington Academy of Sciences 29, 21-36

Grant, R.E. 1976. Permian brachiopods from southern Thailand. Paleontological Society Memoir 9, 1-269.

HAAs, O. 1953. Mesozoic invertebrate faunas of Peru. Bulletin of the American Museum of Natural History 101, 1-328.

HaLl, J. 1858. Description of new species and fossils from the Carboniferous limestones of Indiana and Illinois. Transactions of the Albany Institute 4, 1-36.

Hodre, R.D., Sturgeon, M.T. \& Anderson, J.R. JR. 1997. Pennsylvanian marine gastropods from the Appalachian Basin. Journal of Paleontology 71, 1019-1039.

IshiI, K. \& Murata, M. 1974. Khumerspira, a new genus of Bellerophontidae, and some Middle Permian gastropods from Cambodia. Journal of Geosciences, Osaka City University 17, 73-86.

Ketwetsuriya, C., Nützel, A. \& Kanjanapayont, P. 2014. A new Permian gastropod fauna from the Tak Fa Limestone, Nakhonsawan, Northern Thailand - a report of preliminary results. Zitteliana A 54, 137-146. 
Knight, J.B. 1930. The Gastropods of the St. Louis, Missouri, Pennsylvanian outlier: The Pseudozygopleurinae. Journal of Paleontology 4, 1-89.

Knight, J.B. 1931a. The Gastropods of the St. Louis, Missouri, Pennsylvanian outlier: The Subulitidae. Journal of Paleontology $5,177-229$.

Knight, J.B. 1931b. The Gastropods of the St. Louis, Missouri, Pennsylvanian outlier: Aclisina and Streptacis. Journal of Paleontology 5, 1-15.

Knight, J.B. 1932. The Gastropods of the St. Louis, Missouri, Pennsylvanian outlier: The Pseudomelaniidae. Journal of $\mathrm{Pa}$ leontology 6, 189-202.

Knight, J.B. 1933. The gastropods of the St. Louis, Missouri, Pennsylvanian outlier: V. The Trocho-Turbinidae. Journal of Paleontology 7, 30-58.

Knight, J.B. 1941. Paleozoic gastropod genotypes. Geological Society of America Special Papers 32, 1-510. DOI 10.1130/SPE32-p1

KNight, J.B. 1945. Some new genera of Paleozoic Gastropoda. Journal of Paleontology 19, 573-587.

KNight, J.B. 1956. New families of Gastropoda. Journal of the Washington Academy of Sciences 46, 41-42.

Knight, J.B., Cox, L.R., KeEn, A.M., Batten, R.L., Yochelson, E.L. \& Robertson, R. 1960. Systematic descriptions, I169-I310. In Moore, R.C. (ed.) Treatise on Invertebrate Paleontology, Part I, Mollusca 1. Geological Society of America \& University of Kansas Press, Lawrence.

KoKen, E. 1896. Die Gastropoden der Trias um Hallstadt. Jahrbuch der kaiserlich-königlichen geologischen Reichsanstalt 46, 37-126.

KonINCK, L.G. DE 1881. Faune du calcaire carbonifère de la Belgique, 3e partie, Gastéropodes. Annales du Musée Royal d'Histoire Naturelle de Belgique, serie Paleontologie 6, 1-170.

KonINCK, L.G. DE 1883. Faune du calcaire carbonifère de la Belgique. Quatrième partie, Gastéropodes (suite et fin). Annales du Musée Royal d'Histoire naturelle de Belgique 8, $1-240$.

KuEs, B.S. 1990. New and little known Pennsylvanian gastropods from the Flechado Formation, Taos City, New Mexico. New Mexico Geological Society Guidebook 41, 251-258.

KuEs, B.S. 2002. New genera and species of Middle Pennsylvanian gastropods from West Texas. Journal of Paleontology 76, 52-62.

DOI 10.1666/0022-3360(2002)076<0052:NGASOM>2.0.CO;2

KuES, B.S. 2004. Stratigraphy and brachiopod and molluscan paleontology of the Red Tanks Formation (Madera Group) near the Pennsylvanian-Permian boundary, Lucero uplift, westcentral New Mexico. New Mexico Museum of Natural History and Science Bulletin 25, 143-210.

Kues, B.S. \& BAtTen, R.L. 2001. Middle Pennsylvanian gastropods from the Flechado Formation, north-central New Mexico. Journal of Paleontology 75, Supplement to No. 1, 1-95.

Kulas, H.A. \& Batten, R.L. 1997. Silicified gastropods from the Permian Phosphoria rock complex of Wyoming. Contributions to Geology, University of Wyoming 31, 33-58.

LÉVEILLÉ, C. 1835. Aperçu géologique de quelques localités très riches en coquilles sur les frontières de la France et de Belgique. Mémoires de la Société Géologique de la France 2, 29-40.
Licharev, B.K. 1967. Scaphopods and gastropods - Archaeogastropoda (excluding the suborder Bellerophontina and suborder Neritopsina) from the Upper Paleozoic of southern Fergana. Trudy Vsesoyuznogo naucho-issledovatel'skogo geologo-razvedochnogo instituta, Biostratigrafiya, Nov. Ser. $116,1-115$.

LichaREV, B.K. 1968. Skafopody i gastropody verkhnego karbona i nizhnei permi yuzhnoi Fergany (Scaphopods and gastropods from the Upper Carboniferous and Lower Permian of Southern Fergana). 118 pp. Nedra Press, Moscow.

LichAREV, B.K. 1975. Carboniferous gastropods from the region of the River Kavabolka. Trudy Vsesoyuznogo nauchoissledovatel'skogo geologo-razvedochnogo instituta 206, 5-183.

Lindström, A. \& Peel, J.S. 2005. Repaired injuries and shell form in some Palaeozoic pleurotomarioid gastropods. Bulletin of Geosciences 85, 541-550.

LinSLEy, R.M. \& KIER, W.M. 1984. The Paragastropoda: A proposal for a new class of Paleozoic Mollusca. Malacologia 25, 241-254.

Mansuy, H. 1912. Paléontologie, 1-146. In Mansuy, H. \& Deprat, J. (eds) Etude géologique du Yun-Nan oriental. Actes de la Société Géologique de l'Indo-Chine 1(2).

Mansuy, H. 1913. Faunes des calcaires à Productus de l'Indochine. Mémoires du Service Géologique de l'Indochine 2, fascicule 4, 1-133.

Mansuy, H. 1914a. Nouvelle contribution à la paléontologie du Yunnan. Mémoires du Service Géologique de l'Indochine 3, fascicule 2, 1-190.

Mansuy, H. 1914b. Faunes des calcaires à Productus de 1'Indochine, deuxième série. Mémoires du Service Géologique de l'Indochine 3, fascicule 3, 1-59.

MARK, C.G. 1912. The fossils of the Conemaugh Formation of Ohio. Ohio Geological Survey Bulletin 17, 261-318.

Mazaev, A.V. 1997. Middle and Late Carboniferous gastropods from the Central part of the Russian Plate. Part 3. Microdomatidae and Anomphalidae. Ruthenica 7, 91-110.

MazAev, A.V. 2001. The gastropod genus Stegocoelia Donald, 1889 (Murchisoniidae) from Middle and Upper Carboniferous of the Central part of Russian Plate. Ruthenica 11, $137-151$.

Mazaev, A.V. 2002. Some murchisoniid gastropods from the Middle and Upper Carboniferous part of Russian Plate. Ruthenica 12, 89-106.

Mazaev, A.V. 2006. Permian gastropods from Kulogory Formation of northern Moscow Syneclise. Paleontological Journal 40, 42-53. DOI 10.1134/S0031030106040046

Mazaev, A.V. 2011. Pennsylvanian gastropods of the suborders Murchisoniina Cox et Knight, 1960 and Sinuspirina Mazaev subordo nov. from the central regions of the Russian Platform: Morphology, taxonomy, and phylogeny. Paleontological Journal 45, 1533-1599. DOI 10.1134/S003103011112001X

Mazaev, A.V. 2015. Upper Kazanian (Middle Permian) gastropods of the Volga-Urals Region. Paleontological Journal 49, 869-986. DOI 10.1134/S0031030115080018

McCoy, F. 1844. A synopsis of the characters of Carboniferous Limestone Fossils of Ireland. 274 pp. McGloshan and Gill, Dublin. DOI 10.5962/bhl.title.11559 
McCoy, F., 1852, A synopsis of the classification of the British Palaeozoic rocks [by the Rev. Adam Sedgwick] with a systematic description of the British Palaeozoic fossils in the Geological Museum of the University of Cambridge [by Frederick $\mathrm{McCoy}]$ with figures of the new and imperfectly known species. xcviii + viii pp. [by A. Sedgwick], 661 pp. [by F. McCoy]. Parker \& Son, London.

MeEk, F.B. 1871. Descriptions of new species of fossils from Ohio and other western states and territories. Proceedings of the Academy of Natural Sciences of Philadelphia 23, 159-184.

MeeK, F.B. \& Hayden, F.V. 1858. Remarks on the Lower Cretaceous beds of Kansas and Nebraska, together with descriptions of some new species of Carboniferous fossils from the valley of Kansas River. Proceedings of the Academy of Natural Sciences of Philadelphia 10, 256-264.

Meek, F.B. \& Worthen, A.H. 1861. Descriptions of new Carboniferous fossils from Illinois and other western states. Proceedings of the Academy of Natural Sciences of Philadelphia 12, 447-472.

Meek, F.B. \& Worthen, A.H. 1862. Descriptions of new Palaeozoic fossils from Illinois and Iowa. Proceedings of the Academy of Natural Sciences of Philadelphia 13, 128-148.

Meek, F.B. \& Worthen, A.H. 1866. Descriptions of invertebrates from the Carboniferous system. Geological Survey of Illinois 2, Palaeontology, 143-411.

Meek, F.B. \& Worthen, A.H. 1867. Contributions to the paleontology of Illinois and other western states. Proceedings of the Academy of Natural Sciences of Philadelphia 18, 251-275.

Metcalfe, I. \& Sone, M. 2008. Biostratigraphy and palaeobiogeography of Lower Permian (lower Kungurian) conodonts from the Tak Fa Formation (Saraburi Limestone), Thailand. Palaeogeography, Palaeoclimatology, Palaeoecology 257, 139-151. DOI 10.1016/j.palaeo.2007.09.014

MonTFORT, P.D. DE 1808, 1810. Conchyliologie systématique et classification méthodique de coquilles; offrant leurs figures, leur arrangement générique, leurs descriptions caractéristiques, leurs noms; ainsi que leur synonymie en plusieurs langues. Coquilles univalves, cloisonnées. Vol. 1, 409 pp., Vol. 2, 676 pp. F. Schoell, Paris.

Moore, R.C. 1941. Upper Pennsylvanian gastropods from Kansas. State Geological Survey Kansas, Bulletin 38, 121-164.

NAKornsri, N. 1976. Geological Map of Ban Mi Sheet ND 47-4, Scale 1:250,000, Geological Survey Division. Department of Mineral Resources, Bangkok, Thailand.

NAKORNSRI, N. 1981. Geology and Mineral Resources of Amphoe Ban Mi (ND 47-4), Geological Survey Report Number 3. Department of Mineral Resources, Bangkok, Thailand.

NAPRADIT, T. 2005. Permian Fusulinoidean Limestones from East of Changwat Nakhon Sawan. Master Thesis, Department of Geology, Faculty of Science, Chulalongkorn University, Bangkok, Thailand.

Nechaev, A.V. 1894. Fauna of the Permian beds of the eastern part of European Russia. Trudy Obshchestva estestvoispytatelei pri Imperatorskom Kazanskom universitete 27(4), 1-503 [in Russian; not seen, cited after Mazaev 2015].

Nishida, T. 1969. Middle Permian gastropods from the Takaoka Formation of the Sakawa Basin, Kochi Prefecture, Shikoku, Japan. Saga Daigaku Kyoikugkuba Kenkyu-ronbunshu, Saga Daigaku Kyoikugkuba Kenkyu-ronbunshu 17, 81-105.
NüTZEL, A. 1998. Über die Stammesgeschichte der Ptenoglossa (Gastropoda). Berliner Geowissenschaftliche Abhandlungen, Reihe E 26, 1-229.

NÜtZel, A. \& BANDEL, K. 2000. Goniasmidae and Orthonemidae: two new families of the Palaeozoic Caenogastropoda (Mollusca, Gastropoda). Neues Jahrbuch für Geologie und Paläontologie, Abhandlungen 9, 557-569.

NüTZEL, A. \& ERwIN, D.H. 2004. Late Triassic (Late Norian) gastropods from the Wallowa Terrane (Idaho, USA). Paläontologische Zeitschrift 78, 361-416. DOI 10.1007/BF03009231

NüTzel, A., ERwin, D.H. \& MAPES, R.H. 2000. Identity and phylogeny of the late Paleozoic Subulitoidea (Gastropoda). Journal of Paleontology 74, 575-598. DOI 10.1666/0022-3360(2000)074<0575:IAPOTL >2.0.CO;2

NütZel, A., Frýda, J., Yancey, T.E. \& Anderson, J.R., JR. 2007. Larval shells of Late Palaeozoic naticopsid gastropods (Neritopsoidea: Neritimorpha) with a discussion of the early neritimorph evolution. Paläontologische Zeitschrift 81, 213-228. DOI 10.1007/BF02990173

NütZel, A. \& NAKaZAwa, K. 2012. Permian (Capitanian) gastropods from the Akasaka Limestone (Gifu Prefecture, Japan). Journal of Systematic Palaeontology 10, 103-169. DOI 10.1080/14772019.2010.549659

Orbigny, A. d' 1853. Paléontologie française. Terrains jurassiques. Tome II, Gastropodes. 651 pp. Masson, Paris.

Pan Hua-Zhang \& Erwin, D.H. 2002. Gastropods from the Permian of Guangxi and Yunnan provinces, South China. Journal of Paleontology 78, Supplement to No 1, The Paleontological Society Memoir 56, 1-49.

Pan Yun-TAng \& Yu Wen 1993. Permian Gastropoda of China. 68 pp. Ocean Press, Beijing.

Perner, J. 1907. Système silurien du centre de la Bohême [par J. Barrande]. Partie 1: Recherches paléontologiques. Volume 4, Gastéropodes (2). xi +380 pp. Prague.

PHILIPPS, J. 1836. Illustrations of the geology of Yorkshire; or a description of the strata and organic remains, accompanied by a geological map, sections, and diagrams, and figures of the fossils. $254 \mathrm{pp}$. Murray, London.

RAFINESQUE, C.S. 1815. Analyse de la nature, ou tableau de l'univers et des corps organisées. $223 \mathrm{pp}$. Jean Barravecchia, Palerme. DOI 10.5962/bhl.title.106607

SALVINI-Plawen, L. VON 1980. A reconsideration of systematics in the Mollusca (phylogeny and higher classification). Malacologia 19, 249-278.

Simroth, H. 1906. Versuch einer neuen Deutung der Bellerophontidae. Sitzungsberichte der Natuforschenden Gesellschaft zu Leipzig 32 (1905), 3-8.

Sone, M. 2010. A new species of the rare neritopsid gastropod Magnicapitatus from the Guadalupian (Middle Permian) of East Thailand (the Indochina Terrane). Alcheringa 34, 1-6. DOI 10.1080/03115510903277709

Sowerby, J. 1812-1822. The mineral conchology of Great Britain; or coloured figures and descriptions of those remains of testaceous animals or shells, which have been preserved at various times and depths in the Earth. 803 pp. Benjamin Meredith, London.

StURGEON, M.T. 1964. New descriptions of hitherto inadequality known Pennsylvanian gastropods. Journal of Paleontology $38,739-748$. 
Swainson, W. 1840. A treatise on malacology or shells and shell-fish. viii + 419 pp. Longman, London.

SzABÓ, J. 2011. Corrections to three gastropod genera, established by Kutassy on Late Triassic type species from Dachstein Limestone localities of Budapest (Hungary). Neues Jahrbuch für Geologie und Paläontologie, Abhandlungen 261, 37-47. DOI 10.1127/0077-7749/2011/0145

Thomas, E.G. 1940. Revision of the Scottish Carboniferous Pleurotomariidae. Geological Society of Glasgow Transactions 20, 30-72. DOI 10.1144/transglas.20.1.30

TomLIN, J. R. LE B. 1930. Some preoccupied generic names. II. Proceedings of the Malacological Society of London 19, 22-24.

Ueno, K. \& Charoentitirat, T. 2011. Carboniferous and Permian, 71-135. In Rido, M.F., BARBER, A.J. \& CROw, M.J. (eds) The Geology of Thailand. 626 pp. Geological Society, London.

UlRich, E.O. \& SCOFIELD, W.H. 1897. The lower Silurian Gastropoda of Minnesota, 813-1081. In UlRich, E.O., SCOFIELD, W.H., Clarke, J.M. \& Winchell, N.H. The geological and natural history survey of Minnesota. Vol. 3, part 2, The Geology of Minnesota. Paleontology.

WaAgen, W. 1880. Salt-Range Fossils. I. Productus Limestone Fossils. 2. Pisces-Cephalopoda: Supplement Gasteropoda. Memoirs of the Geological Survey of India (Palaeontologia Indica) 13, 1-183.

WANNER, J. 1942. Neue Beiträge zur Gastropoden-Fauna des Perm von Timor. Geological Expedition of the University of Amsterdam to the Sunda Islands, 137-203.

WARTHIN, A.S. 1930. Micropaleontology of the Wetumka, Wewoka and Holdenville formations. Oklahoma Geological Survey Bulletin 53, 5-94.

Waterhouse, J.B. 1982. An Early Permian cool-water fauna from pebbly mudstones in south Thailand. Geological Magazine 119, 337-354. DOI 10.1017/S0016756800026261

WELLER, J.M. 1930. A new species of Euphemus. Journal of Paleontology 4, 14-21.

Wenz, W. 1938-1944. Gastropoda. Teil 1: Allgemeiner Teil und Prosobranchia. In Schindewolf, O.H. (ed.) Handbuch der
Paläozoologie, Band 6, Gastropoda. 1639 pp. Borntraeger, Berlin.

White, C.A. 1877. Report upon the invertebrate fossils collected in portions of Nevada, Utah, Colorado, New Mexico, and Arizona, by parties of the expeditions of 1871, 1872, 1873, and 1874. Report upon United States geographical surveys west of the one hundredth meridian. Vol. 4, Paleontology, 1-219. Government Printing Office, Washington.

Wielchowsky, C.C. \& Young, J.D. 1985. Regional facies variations in Permian rocks of the Phetchabun fold and thrust belt, Thailand. Conference on the Geology and Mineral Resource Development of NE Thailand, 41-55.

WinTERs, S.S. 1956. New Permian gastropod genera from eastern Arizona. Journal of the Washington Academy of Sciences 42, 44-45.

Worthen, A.H. 1890. Descriptions of fossil invertebrates. Illinois Geological Survey Bulletin 8, 69-154.

YAKOwLEW, N.N. 1899. Die Fauna einiger oberpaläozooischer Ablagerungen Russlands. 1. Die Cephalopoden und Gasteropoden, Russia. Trudy Geologicheskogo komiteta, Saint Petersburg 15, 1-139.

Yochelson, E.L. 1956. Permian Gastropoda of the southwestern United States. 1. Euomphalacea, Trochonematacea, Anomphalacea, Craspedostomatacea, and Platyceratacea. Bulletin of the American Museum of Natural History 110, 179-275.

Yochelson, E.L. 1960. Permian Gastropoda of the southwestern United States. Bulletin of the American Museum of Natural History 119, 205-294.

Yochelson, E.L. \& SAunders, B.W. 1967. A bibliographic index of North American Late Paleozoic Hyolitha, Amphineura, Scaphopda, and Gastropoda. Geological Survey Bulletin 1210, 1-271.

ZitTel, K.A. 1881-1885. Handbuch der Palaeontologie 2. Mollusca und Arthropoda. 900 pp. R. Oldenbourg, München \& Leipzig.

ZitTel, K.A. von 1895. Grundzüge der Paläontologie (Paläozoologie), Abt. I, Invertebrata. 971 pp. R. Oldenbourg, München \& Leipzig. 